
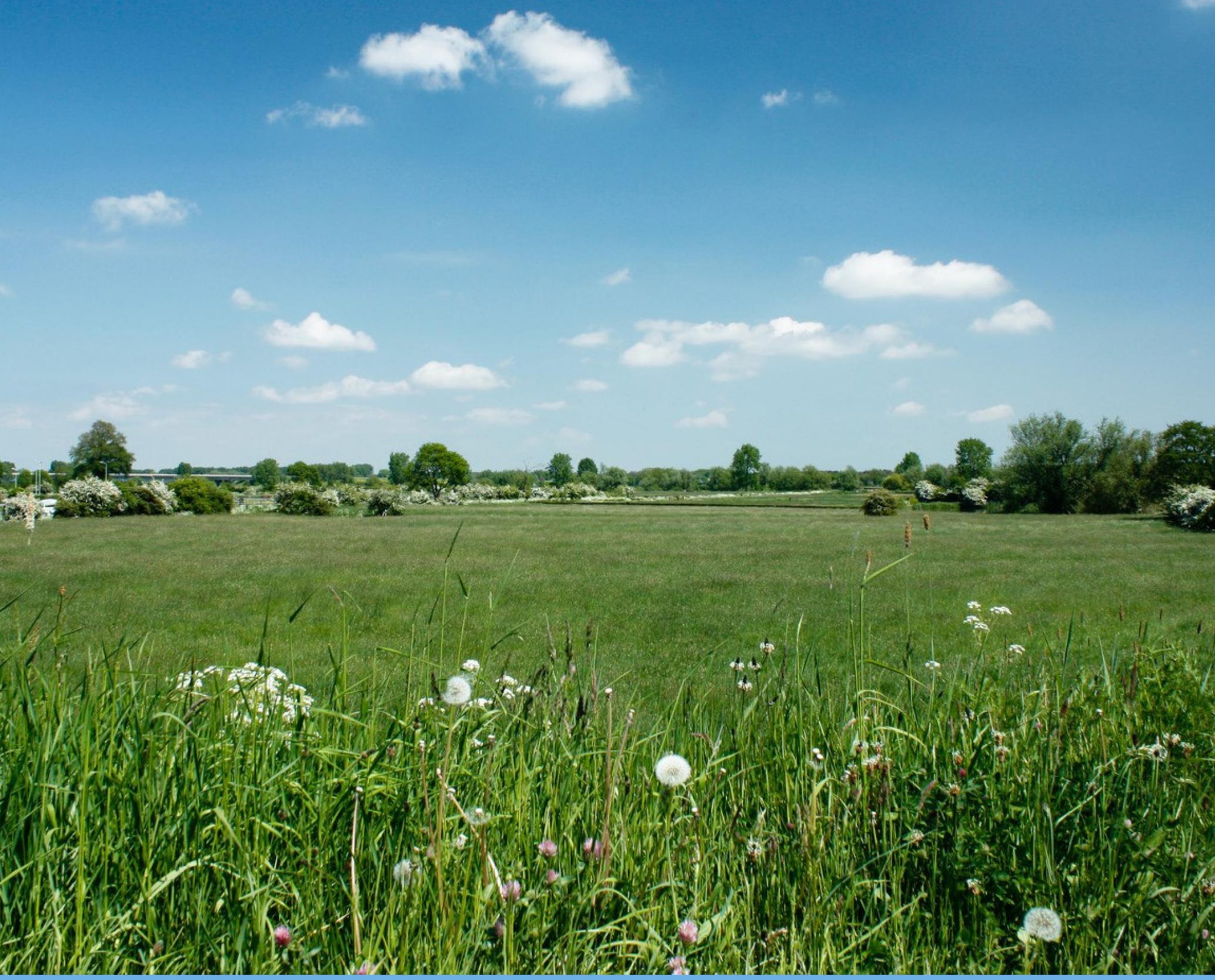

\title{
Barometer agrarische sector in de gemeente Berkelland
}

R. Stokkers en A. Wisman 



\section{Barometer agrarische sector in de gemeente Berkelland}

R. Stokkers en A. Wisman

Dit onderzoek is uitgevoerd door Wageningen Economic Research in opdracht van en gefinancierd door de gemeente Berkelland.

Wageningen Economic Research

Wageningen, september 2020

RAPPORT

2020-075

ISBN 978-94-6395-520-1 
Stokkers, R., A. Wisman, 2020. Barometer agrarische sector in de gemeente Berkelland. Wageningen, Wageningen Economic Research, Rapport 2020-075. 28 blz.; 12 fig.; 10 tab.; 9 ref.

In 2019 telt de gemeente Berkelland 663 land- en tuinbouwbedrijven. Zij hebben samen 17.700 hectare cultuurgrond in gebruik, bieden werkgelegenheid voor 1.250 arbeidsjaren en realiseren een standaardopbrengst van 182 miljoen euro. Na afronding van de gemeentelijke herindeling in 2005 met een iets kleiner grondgebied tot gevolg, is de ontwikkeling van deze kengetallen in Berkelland tot 2019 vergelijkbaar met de rest van de Achterhoek en Nederland. De belangrijkste bedrijfstypen zijn de gespecialiseerde melkvee- en varkensbedrijven en hiervan heeft respectievelijk $70 \%$ en $50 \%$ een verdiencapaciteit groter dan 50.000 euro en is veelal verzekerd van bedrijfsopvolging.

Trefwoorden: Berkelland, agrarische barometer, melkveehouderij, varkenshouderij

Dit rapport is gratis te downloaden op https://doi.org/10.18174/530133 of op www. wur. nl/economicresearch (onder Wageningen Economic Research publicaties).

(C) 2020 Wageningen Economic Research

Postbus 29703, 2502 LS Den Haag, T 07033583 30, E communications.ssg@wur.nl, www.wur.nl/economic-research. Wageningen Economic Research is onderdeel van Wageningen University \& Research.

\section{(cc) BY-NC}

Dit werk valt onder een Creative Commons Naamsvermelding-Niet Commercieel 4.0 Internationaallicentie.

(c) Wageningen Economic Research, onderdeel van Stichting Wageningen Research, 2020

De gebruiker mag het werk kopiëren, verspreiden en doorgeven en afgeleide werken maken. Materiaal van derden waarvan in het werk gebruik is gemaakt en waarop intellectuele eigendomsrechten berusten, mogen niet zonder voorafgaande toestemming van derden gebruikt worden. De gebruiker dient bij het werk de door de maker of de licentiegever aangegeven naam te vermelden, maar niet zodanig dat de indruk gewekt wordt dat zij daarmee instemmen met het werk van de gebruiker of het gebruik van het werk. De gebruiker mag het werk niet voor commerciële doeleinden gebruiken.

Wageningen Economic Research aanvaardt geen aansprakelijkheid voor eventuele schade voortvloeiend uit het gebruik van de resultaten van dit onderzoek of de toepassing van de adviezen.

Wageningen Economic Research is ISO 9001:2015 gecertificeerd.

Wageningen Economic Research Rapport 2020-075 | Projectcode 2282200518

Foto omslag: Shutterstock 


\section{Inhoud}

Samenvatting $\quad 5$

S.1 Belangrijkste uitkomsten $\quad 5$

$\begin{array}{lll}\text { S.2 Overige uitkomsten } & 6\end{array}$

$\begin{array}{lll}\mathrm{S} .3 \text { Methode } & 6\end{array}$

$\begin{array}{lll}1 & \text { Inleiding } & 7\end{array}$

$\begin{array}{lll}1.1 & \text { Context } & 7\end{array}$

$\begin{array}{lll}1.2 & \text { Doel } & 7\end{array}$

$\begin{array}{lll}1.3 & \text { Werkwijze } & 7\end{array}$

$\begin{array}{lll}1.4 & \text { Leeswijzer } & 7\end{array}$

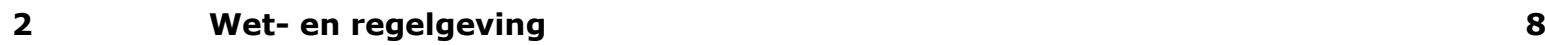

$3 \quad$ Agrarisch Berkelland in 2005-2019 $\quad 11$

$\begin{array}{lll}3.1 & \text { Aantal bedrijven } & 11\end{array}$

3.2 Areaal cultuurgrond $\quad 13$

3.3 Veestapel 15

3.4 Arbeid 16

$\begin{array}{lll}3.5 & \text { Standaardopbrengst } & 17\end{array}$

$\begin{array}{lll}3.6 & \text { Verdienvermogen } & 19\end{array}$

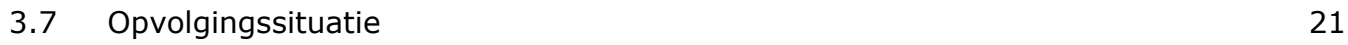

$\begin{array}{lll}3.8 & \text { Biologische landbouw } & 23\end{array}$

3.9 Verbreding 23

$\begin{array}{ll}\text { Literatuur en websites } & 24\end{array}$

Bijlage $1 \quad$ NSO-typering voor Berkelland $\quad 25$

Bijlage 2 Statistieken gespecialiseerde melkvee- en varkensbedrijven 26 



\section{Samenvatting}

\section{S.1 Belangrijkste uitkomsten}

In de periode 2005-2019 is het totaalaantal agrarische bedrijven in Berkelland afgenomen van 999 naar 663 bedrijven. Deze daling van gemiddeld 2,9\% per jaar is vergelijkbaar met de rest van de Achterhoek en Oost-Nederland en iets lager dan in geheel Nederland. De verdeling over bedrijfstypen is als volgt: $40 \%$ melkveebedrijven, $25 \%$ overige graasdierbedrijven, $10 \%$ varkensbedrijven en $25 \%$ overige bedrijven. Laatstgenoemde groep bestaat merendeels uit akkerbouwbedrijven en dan vooral die met voedergewassen. Dit zijn met name voormalige melkvee- en overige graasdierbedrijven zonder bedrijfsopvolging, die hun veestapel al hebben afgestoten en gras en snijmais telen voor derden.

In de periode 2005-2019 is het areaal cultuurgrond in Berkelland afgenomen van 20.300 naar 17.700 hectare. Deze daling van gemiddeld $0,95 \%$ per jaar is beduidend groter dan de jaarlijkse daling van 0,45 tot $0,50 \%$ in geheel Nederland. Bij nadere bestudering blijkt dit waarschijnlijk het gevolg te zijn van de gemeentelijke herindeling in 2005, waarbij de buurschappen Mariënvelde en Zwolle werden toegevoegd aan de nieuwe gemeente Oost Gelre in plaats van aan Berkelland en de agrarische bedrijven in die buurschappen administratief zijn meeverhuisd. Nadien houdt de daling in Berkelland wel gelijke tred met de rest van Nederland.

De ontwikkeling van de veestapel in Berkelland in de periode 2005-2019 verschilt sterk per diersoort. Het aantal melkkoeien is door de jaren heen vrij stabiel gebleven op rond de 25.000 stuks, maar het aantal varkens is met 2 procent per jaar gedaald tot 207.500 stuks. Daarentegen is het aantal geiten sinds 2005 ruimschoots verdubbeld tot 8.500 stuks.

In de periode 2005-2019 is de werkgelegenheid in de land- en tuinbouw in Berkelland afgenomen van 1.660 naar 1.250 arbeidsjaareenheden (aje), een daling van gemiddeld 2,0\% per jaar.

De standaardopbrengst (SO) is een maat voor de gemiddelde omzet onder standaardomstandigheden en is in de periode 2005-2019 in de land- en tuinbouw in Berkelland gestegen van 151 naar 182 miljoen euro, een groei van gemiddeld $1,35 \%$ per jaar.

De geconstateerde verschillen in ontwikkeling van de werkgelegenheid en standaardopbrengsten met de Achterhoek en de rest van Nederland lijken eveneens het gevolg van de gemeentelijke herindeling in 2005. Nadien houden deze ontwikkelingen wel gelijke tred.

In 2014 ontwikkelde Wageningen Economic Research een nieuw kengetal om beter inzicht te verschaffen in de toegevoegde waarde van een bedrijf dan alleen de standaardopbrengst. Dit is de standaardverdiencapaciteit (SVC) en deze weerspiegelt het vermogen om een inkomen te genereren onder standaard omstandigheden en houdt rekening met verschillen in toegevoegde waarde tussen agrarische producten als bijvoorbeeld melk en varkens. In de periode 2010-2019 is de standaardverdiencapaciteit per bedrijf in de land- en tuinbouw in Berkelland gestegen van 36.000 naar 60.000 euro, een groei van gemiddeld $5,7 \%$ per jaar. Dit beeld is min of meer vergelijkbaar met de Achterhoek, maar de verdiencapaciteit en groei zijn wel kleiner dan in Oost-Nederland en Nederland als geheel door het vrijwel ontbreken van (glas)tuinbouwbedrijven.

Het aantal biologische bedrijven in Berkelland is al sinds 2005 stabiel met 6 of 7 bedrijven en hun aandeel in het totale areaal cultuurgrond bedraagt ongeveer $0,5 \%$ en is daarmee beduidend lager dan voor heel Nederland.

Volgens de landbouwtelling van 2016 hield in Berkelland $21 \%$ van de land- en tuinbouwbedrijven zich bezig met verbreding, ofwel met bedrijfsmatige activiteiten anders dan landbouw. Deze activiteiten betreffen vooral natuurbeheer (7\%), duurzame energieproductie voor eigen bedrijf (6\%), loonwerk $(4 \%)$, recreatie $(3 \%)$, verkoop van producten (3\%) en stalling van bijvoorbeeld caravans $(2 \%)$. 


\section{S.2 Overige uitkomsten}

In Tabel S.1 zijn de belangrijkste kenmerken van de agrarische bedrijven in de gemeente Berkelland samengevat, opgesplitst naar de bedrijfstypen melkveebedrijven, overige graasdierbedrijven, varkensbedrijven en overige bedrijven. Van de gespecialiseerde melkvee- en varkensbedrijven heeft respectievelijk $70 \%$ en $50 \%$ een verdiencapaciteit groter dan 50.000 euro en deze bedrijven zijn veelal verzekerd van bedrijfsopvolging. Ze hebben over het algemeen fors geïnvesteerd in stallen en productierechten en zijn behoudens grote onverwachte wijzigingen in de wet- en regelgeving klaar voor de toekomst. De overige graasdierbedrijven en overige bedrijven met nauwelijks vee weten over het algemeen geen volwaardig inkomen te realiseren uit de landbouw: respectievelijk 95\% en $75 \%$ heeft een verdiencapaciteit kleiner dan 35.000 euro (modaal) en slechts een klein deel van deze bedrijven heeft een bedrijfsopvolger.

De verwachting is dat de schaalvergroting en specialisatie in agrarisch Berkelland net als elders in het land de komende jaren zal doorzetten, waarbij de daling bij de gespecialiseerde melkveebedrijven als gevolg van een verhoging van de kritieke kostprijs in de afgelopen vier jaren met circa $10 \%$ vanwege extra milieu-investeringen, naar verwachting beduidend groter zal zijn dan in voorgaande jaren.

Tabel S.1 Kenmerken agrarische bedrijven in Berkelland naar bedrijfstype, 2019.

\begin{tabular}{|c|c|c|c|c|c|}
\hline & $\begin{array}{l}\text { Melkvee- } \\
\text { bedrijven }\end{array}$ & $\begin{array}{l}\text { Overige graas- } \\
\text { dierbedrijven }\end{array}$ & $\begin{array}{l}\text { Varkens- } \\
\text { bedrijven }\end{array}$ & $\begin{array}{l}\text { Overige } \\
\text { bedrijven }\end{array}$ & Totaal \\
\hline Aantal bedrijven & 261 & 169 & 63 & 170 & 663 \\
\hline Aantal melkkoeien & 88 & - & - & - & - \\
\hline Aantal varkens & - & - & 2.901 & - & - \\
\hline Standaardopbrengst (in 1.000 euro) & 364 & 90 & 733 & 153 & 275 \\
\hline Verdiencapaciteit (in 1.000 euro) & 97 & 18 & 94 & 31 & 60 \\
\hline Bedrijven zonder opvolger in 2016 (in \%) & 31 & 60 & 44 & 46 & 43 \\
\hline
\end{tabular}

Bron: CBS Landbouwtelling, bewerking Wageningen Economic Research.

\section{S.3 Methode}

De gemeente Berkelland zet in haar collegeprogramma in op een vitaal en innovatief buitengebied en heeft daarom behoefte aan een actueel beeld van de landbouw, de ontwikkelingen in de afgelopen jaren en een eerste doorkijk naar de toekomst. De gemeente heeft Wageningen Economic Research daarom opdracht gegeven om een agrarische barometer te vervaardigen voor Berkelland.

Met behulp van de jaarlijkse CBS Landbouwtelling wordt een beeld geschetst van de ontwikkeling van de land- en tuinbouwbedrijven in de gemeente Berkelland in de periode 2005-2019 met als benchmark de agrarische ontwikkelingen op regionaal en/of nationaal niveau. Deze ontwikkelingen zijn getoetst in vijf diepte-interviews met informanten uit de agrarische accountancy en advies in Berkelland. 


\section{$1 \quad$ Inleiding}

\subsection{Context}

De gemeente Berkelland zet in haar collegeprogramma in op een vitaal en innovatief buitengebied en heeft daarom behoefte aan een actueel beeld van de landbouw, de ontwikkelingen in de afgelopen jaren en een eerste doorkijk naar de toekomst. Dit biedt de gemeente inzicht in de ontwikkeling van vrijkomende agrarische bebouwing, de mogelijkheden voor nieuwe economische activiteiten en de mogelijk faciliterende rol van de gemeente in het stimuleren van kansrijke innovaties.

$\mathrm{Er}$ is een aantal mooie kansen: de natuur, het coulisselandschap en de mooie dorpsgezichten, het materieel en immaterieel erfgoed, de agrarische sector en allerlei recreatieve voorzieningen. Er is evenwel ook een aantal bedreigingen: de asbestproblematiek, het gebrek aan opvolgers binnen de agrarische sector, de mogelijke verpaupering vanwege vrijkomende agrarische bebouwing en de vergrijzing in de dorpskernen.

De gemeente zet in op een beleid dat bestaande ondernemers ondersteunt en nieuwe ondernemers uitnodigt en faciliteert, ook qua ruimtelijke ordening. Het gaat hierbij om bestaande en nieuwe vormen van landbouw (verticaal, circulair, natuurinclusief), maar ook om nieuwe verdienmodellen in het buitengebied (bijvoorbeeld zorg, kinderopvang, toerisme, biodiversiteit, energie) en wellicht ook nog andere vormen van (niet-agrarische) bedrijvigheid.

\subsection{Doel}

Het doel van dit project is om de gemeente Berkelland een actueel beeld te verschaffen van de ontwikkelingen in de agrarische sector in Berkelland in de afgelopen jaren.

\subsection{Werkwijze}

Met behulp van de Barometer Duurzame Landbouw van Wageningen Economic Research wordt inzicht gegeven in de structuur van de land- en tuinbouw in de gemeente Berkelland. Een belangrijke database die daarbij wordt gebruikt is de jaarlijkse CBS Landbouwtelling. Op deze wijze wordt een beeld geschetst van de agrarische ontwikkelingen in de gemeente Berkelland in de afgelopen decennia met als benchmark de agrarische ontwikkelingen op regionaal en/of nationaal niveau. Deze ontwikkelingen zijn vervolgens getoetst in vijf diepte-interviews met informanten uit de agrarische accountancy en advies in Berkelland.

\subsection{Leeswijzer}

In hoofdstuk 2 volgt eerst een beknopt overzicht van de belangrijkste wetten, regelingen en besluiten met betrekking tot huisvesting, bemesting en emissies in de veehouderij, die in het verdere rapport ter sprake komen. Hoofdstuk 3 schetst een beeld van de ontwikkeling van de land- en tuinbouw in de gemeente Berkelland in de periode 2005-2019 met als benchmark de Achterhoek en Oost-Nederland en totaal Nederland. 


\section{Wet- en regelgeving}

Er wordt in dit rapport een aantal keren verwezen naar wet- en regelgeving voor de agrarische sector en in het bijzonder met betrekking tot huisvesting, bemesting en emissies in de veehouderij. Daarom volgt in dit hoofdstuk eerst een beknopt overzicht van de belangrijkste wetten, regelingen en besluiten (bronnen: www.agriholland.nl en www.rijksoverheid.nl).

\section{Wet ammoniak en veehouderij (Wav)}

De Wav vormt een onderdeel van de ammoniakregelgeving voor dierenverblijven van veehouderijen. Deze regelgeving werd in 2002 van kracht en heeft als doel de ammoniakuitstoot in Nederland terug te dringen. In 1 mei 2007 werd de wet aangepast. Voor een aantal gebieden geldt extra beleid met als doel de neerslag van ammoniak op zeer kwetsbare natuurgebieden te verminderen. De Wav geldt voor alle veehouderijbedrijven die een omgevingsvergunning milieu nodig hebben.

In de wet is bepaald dat binnen zeer kwetsbare natuurgebieden en in een zone van 250 meter daaromheen in aanvulling op de algemene eisen de volgende maatregelen gelden:

- Vestiging van nieuwe intensieve veehouderijen is niet meer mogelijk.

- Bestaande veehouderijen hebben beperkte uitbreidingsmogelijkheden tot een voor deze veehouderijen vastgelegd emissieplafond van ammoniak. Een uitzondering gold hierbij voor melkveehouderijen. Zij kunnen doorgroeien tot maximaal 200 melkkoeien en 140 stuks jongvee. Daarnaast zijn er uitzonderingen voor uitbreidingen met paarden en schapen, voor biologische bedrijven en bedrijven die dieren voor natuurbeheer houden.

Veel intensieve veehouderijen zijn sinds 1 januari 2013 onder het Activiteitenbesluit komen te vallen. De ammoniakeisen uit de Wav zijn hierin overgenomen. Het Activiteitenbesluit stelt eisen aan diverse milieuthema's. Het thema 'ammoniak' is er daar één van. De activiteiten 'houden van dieren' en 'opslaan van drijfmest en digestaat' veroorzaken uitstoot van ammoniak, wat negatieve effecten heeft op daarvoor gevoelige natuur. Daarom worden in het Activiteitenbesluit eisen gesteld aan de stalsystemen en luchtwassers en er zijn regels opgenomen ter bescherming van kwetsbare natuurgebieden.

\section{Regeling ammoniak en veehouderij (Rav)}

De Rav is een op de Wet ammoniak en veehouderij gebaseerde ministeriële regeling die de emissiefactoren bevat die nodig zijn om in de vergunde en in de aangevraagde situatie de ammoniakemissie van een veehouderij te kunnen berekenen. De Rav bevat een lijst met de verschillende stalsystemen per diercategorie en de daarbij behorende emissiefactoren. De lijst wordt regelmatig geactualiseerd door het ministerie van Infrastructuur en Milieu. De Regeling ammoniak en veehouderij is op 1 juli 2015 voor het laatst gewijzigd. Toen zijn de bestaande maximale emissiewaarden voor rundvee, varkens en pluimvee aangescherpt en een aantal nieuwe maximale emissiewaarden voor ammoniak aan de regeling toegevoegd. De aangescherpte maximale emissiewaarden gelden voor nieuwe stallen en uitbreidingen van bestaande stallen. De actuele emissiefactoren worden gebruikt voor het berekenen van de ammoniakemissie uit stallen bij het verlenen van een vergunning.

\section{Besluit emissiearme huisvesting}

Het Besluit emissiearme huisvesting bepaalt dat dierenverblijven emissiearm moeten zijn, als er emissiearme huisvestingssystemen beschikbaar zijn. Het besluit bevat maximale emissiewaarden: alleen huisvestingssystemen met een emissiefactor die lager is dan of gelijk is aan de maximale emissiewaarde zijn toegestaan. De maximale emissiewaarden voor ammoniak gelden voor melkvee, vleeskalveren, varkens, kippen, vleeskalkoenen en vleeseenden. Het nieuwe besluit vervangt vanaf 1 augustus 2015 het Besluit ammoniakemissie huisvesting veehouderij. De nieuwe normen voor de emissie gaan gelden voor stallen die na 1 juli 2015 worden gebouwd. Ook bij uitbreidingen van stallen met meer dan $50 \%$ van de bestaande capaciteit zijn de nieuwe normen van kracht. 
Voor bestaande stallen gelden wat minder strenge eisen, waar bedrijven zo nodig al eerder aanpassingen voor hebben gedaan. Bedrijven hebben hier op grond van het Actieplan ammoniak veehouderij tot 1 januari 2014 de tijd voor gehad. Voor varkens- en pluimveehouders die te kennen hebben gegeven uiterlijk in 2020 te willen stoppen met hun bedrijf gelden in het Actieplan andere regels. Zij mochten tot 1 april 2013 ook andere en minder kostbare maatregelen nemen om te zorgen voor een verlaging van de ammoniakuitstoot, bijvoorbeeld door aangepast veevoer te gebruiken of een ander soort strooisel toe te passen. Om in aanmerking te komen voor dit gedoogbeleid dienden de betreffende veehouderijen vóór 1 april 2010 een bedrijfsontwikkelingsplan bij het bevoegd gezag in te dienen. Aan de hand van de in het bedrijfsontwikkelingsplan vermelde gegevens kon worden afgeleid tot welke gedoogcategorie de veehouderij hoorde en kon worden vastgesteld wanneer de aanvraag van de benodigde vergunningen moest zijn ingediend en wanneer de stalaanpassingen moesten zijn gerealiseerd.

De landelijke stoppersregeling van het Actieplan ammoniak eindigt op 1 januari 2020. Dit betekent dat alle stallen vanaf 1 januari 2020 moeten voldoen aan het Besluit emissiearme huisvesting. Als een varkens- of pluimveebedrijf is aangemeld voor de stoppersregeling en inderdaad besluit te stoppen, dan mag het op 1 januari 2020 geen varkens c.q. pluimvee meer houden. Als de ondernemer toch besluit om door te gaan, dan moet het bedrijf op 1 januari 2020 voldoen aan de dan geldende normen. Dat betekent dat een nieuwe omgevingsvergunning moet worden aangevraagd of een melding Activiteitenbesluit moet worden gedaan en het bedrijf op 1 januari 2020 in werking moet zijn zoals aangegeven in de nieuwe vergunning of melding.

\section{Programma Aanpak Stikstof (PAS)}

Het PAS steunde op twee pijlers om de doelen van Natura 2000 zeker te stellen. Er werd ingezet op een daling van de stikstofdepositie en daarnaast op ecologische herstelmaatregelen. Een deel van de daling van de stikstofdepositie die werd gerealiseerd mocht weer worden gebruikt voor nieuwe economische activiteiten. Dit werd aangeduid als ontwikkelingsruimte. De staatssecretaris van Economische Zaken heeft in maart 2014 met het agrarisch bedrijfsleven via het Convenant Programmatische Aanpak Stikstof afspraken gemaakt om de uitstoot van ammoniak verder te verminderen. Individuele initiatiefnemers konden bij hun vergunningaanvraag voor nieuwe en uitbreiding van bestaande activiteiten een beroep doen op het PAS en deze leverde dan de onderbouwing dat er geen natuur-doelen in gevaar zouden komen. Op basis van het PAS werd vooruitlopend op toekomstige positieve gevolgen van maatregelen voor beschermde natuurgebieden, alvast toestemming gegeven voor activiteiten die mogelijk schadelijk zijn voor die gebieden, zoals veehouderij en de aanleg van wegen.

In mei 2017 stelde de Afdeling bestuursrechtspraak van de Raad van State vragen aan het Europese Hof van Justitie over het PAS, omdat zij twijfelde of het programma wel voldeed aan de voorwaarden van de Europese Habitatrichtlijn. Het Europese Hof oordeelde in november 2018 dat ook bij het PAS de positieve gevolgen van de maatregelen die in dat programma zijn opgenomen, vooraf vast moeten staan en dat de overheid pas dan een nieuwe activiteit kan toestaan. Omdat het PAS niet aan die voorwaarde voldoet, mag het niet als toestemmingsbasis voor nieuwe activiteiten worden gebruikt. Bovendien wordt in het PAS toestemming voor activiteiten gegeven op basis van maatregelen in natuurgebieden, die nodig zijn voor het voorkomen van achteruitgang van die gebieden en ook dat mag niet. De conclusie is derhalve dat de onderbouwing van het PAS niet deugt. De Afdeling bestuursrechtspraak van de Raad van State zet daarom een streep door de vergunningen voor veehouderijen die in de uitspraak van 29 mei 2019 aan de orde zijn en waarbij gebruik is gemaakt van het PAS. Tegen die uitspraak is geen hoger beroep mogelijk.

\section{Wet grondgebonden groei melkveehouderij en stelsel van fosfaatrechten}

De Nederlandse veehouderij heeft in $\mathbf{2 0 1 5}$ meer fosfaat geproduceerd dan is toegestaan op basis van Europese afspraken. Omdat de melkveehouderij na het afschaffen van het melkquotum sterk is gegroeid, is het productieplafond voor fosfaat overschreden. Als opvolger van de Regeling Fosfaatreductieplan 2017 is er sinds 1 januari 2018 het stelsel van fosfaatrechten voor melkvee om ervoor te zorgen dat de productie van fosfaat onder het fosfaatplafond komt en blijft. Het stelsel richt zich alleen op landbouwbedrijven met bedrijfsmatig gehouden melkvee. Het aantal geregistreerde fosfaatrechten per bedrijf geeft aan hoeveel mest door melkvee geproduceerd mag worden. Deze maatregel is als wet Grondgebonden groei melkveehouderij opgenomen in de Meststoffenwet. 
Het stelsel van fosfaatrechten is een aanvulling op al bestaande stelsels, zoals de gebruiksnormen en -voorschriften, de mestverwerkingsplicht en de Verantwoorde Groei Melkveehouderij (VGM).

\section{Subsidieregeling sanering varkenshouderijen (Srv).}

De beheersing van de landelijke mestproductie van varkens en pluimvee is onderdeel van het mestbeleid. Een bedrijf mag gemiddeld genomen in een kalenderjaar niet meer varkens, kippen of kalkoenen houden dan het aantal dierproductierechten.

Een nieuw instrument is de Subsidieregeling sanering varkenshouderijen. Vanaf 25 november 2019 kunnen varkenshouders in de concentratiegebieden Oost en Zuid van de Meststoffenwet (delen van Noord-Brabant, Limburg, Gelderland, Overijssel en Utrecht) zich bij de Rijksdienst voor Ondernemend Nederland aanmelden voor deelname. Door deel te nemen aan de regeling kunnen zij een vergoeding ontvangen voor het laten doorhalen van hun varkensrecht en daarmee hun bedrijf beëindigen. Ook ontvangen boeren een vergoeding voor het waardeverlies van de stallen. De Srv draagt in eerste instantie bij aan het verminderen van de geuroverlast en het verbeteren van de leefomgeving, maar ook aan het terugdringen van uitstoot van stoffen zoals ammoniak.

Na sluiting van de inschrijvingsperiode wordt onder de aanmeldingen een selectie gemaakt van varkenshouders die met de regeling van start kunnen gaan. Varkenshouders ontvangen uiterlijk drie maanden na sluiting van de openstellingsperiode uitsluitsel over hun deelname. In het voorjaar van 2020 gaat het afbouwen plaatsvinden. Begeleiding vanuit gemeentes is mogelijk. Er is vervolgens acht maanden de tijd om de varkens af te voeren en mest op te ruimen. Na 14 maanden moeten de stallen zijn gesloopt en mag op de locatie van het bedrijf geen intensieve veehouderij meer plaatsvinden. 


\section{Agrarisch Berkelland in 2005-2019}

In dit hoofdstuk wordt op basis van de CBS Landbouwtelling een beeld geschetst van de ontwikkeling van de land- en tuinbouwsector in de gemeente Berkelland in de periode 2005-2019. De gemeente Berkelland is per 1 januari 2005 ontstaan uit een gemeentelijke herindeling van de voormalige gemeenten Borculo, Eibergen, Neede en Ruurlo en behoort met een oppervlakte van 284,71 km² nu tot de 10 grootste plattelandsgemeenten van Nederland. Als benchmark wordt de ontwikkeling in de Achterhoek en Oost-Nederland en Nederland als geheel weergegeven.

Leidend voor opname van een bedrijf in de Landbouwtelling, is dat het is ingeschreven als agrarisch bedrijf in het Handelsregister van de Kamer van Koophandel. Deze afbakening sluit zo nauw mogelijk aan bij de statistische verordeningen van Eurostat en de Nederlandse implementatie van het begrip 'actieve landbouwer' uit het Gemeenschappelijk Landbouwbeleid. Bovendien wordt een ondergrens gehanteerd voor de economische omvang en wel minimaal een Standaard Opbrengst van 3.000 euro.

In de statistieken worden de land- en tuinbouwbedrijven op basis van hun activiteiten en de hierbij horende Standaard Opbrengsten volgens het NSO-typeringsysteem, ingedeeld in 37 verschillende bedrijfstypen en acht hoofdtypen (Van Everdingen en Wisman, 2018). In dit rapport worden vier clusters van bedrijfstypen onderscheiden, namelijk melkveebedrijven, overige graasdierbedrijven, varkensbedrijven en overige bedrijven. Een bedrijf wordt tot een van de drie eerstgenoemde clusters gerekend, als minimaal twee derde van de Standaard Opbrengsten uit de bijbehorende groep van producten afkomstig is. In Bijlage 1 is deze clustering geïllustreerd voor de gemeente Berkelland in 2019. In Bijlage 2 zijn bovendien specifiek voor de gespecialiseerde melkvee- en varkensbedrijven in Berkelland een aantal structuurgegevens opgenomen met als benchmark de Achterhoek, OostNederland en totaal Nederland.

\subsection{Aantal bedrijven}

In de periode 2005-2019 is het totaal aantal agrarische bedrijven in Berkelland afgenomen van 999 naar 663 bedrijven. Deze daling van gemiddeld 2,9\% per jaar is vergelijkbaar met de rest van de Achterhoek en Oost-Nederland en iets lager dan in geheel Nederland (Figuur 3.1 en Tabel 3.1).

De verdeling over de (clusters van) bedrijfstypen is als volgt: $40 \%$ melkveebedrijven, $25 \%$ overige graasdierbedrijven, $10 \%$ varkensbedrijven en $25 \%$ overige bedrijven. De groep melkveebedrijven daalt in de afgelopen 14 jaar langzamer dan gemiddeld. De groep overige graasdierbedrijven is breed samengesteld uit bedrijven met geiten, schapen, paarden, vleeskalveren, vleesvee of combinaties daarvan en daalt iets sneller dan gemiddeld. Bij de groep gespecialiseerde varkensbedrijven heeft de grootste uitstroom plaatsgevonden, namelijk met ruim 6\% per jaar. In 2019 zijn er in Berkelland nog 63 gespecialiseerde varkensbedrijven actief en daarnaast zijn er nog 35 andere bedrijven die varkens houden, veelal in combinatie met andere graas- en hokdieren, maar die uit de varkens alleen minder dan twee derde van hun Standaard Opbrengsten realiseren. De groep 'overige bedrijven' bestaat voor twee derde uit akkerbouwbedrijven en dan vooral met voedergewassen. Dit zijn met name voormalige melkvee- en overige graasdierbedrijven zonder bedrijfsopvolging, die hun veestapel al hebben afgestoten en gras en snijmais telen voor derden. Die bedrijven zullen op termijn worden beëindigd, maar mede gezien de emotionele band met het bedrijf en de wens nog enigszins actief te blijven wordt niet direct gestopt met de agrarische activiteiten. Door de constante instroom uit de andere (clusters van) bedrijfstypen is de daling van het aantal overige bedrijven beduidend kleiner dan gemiddeld.

De verwachting is dat de schaalvergroting en specialisatie in agrarisch Berkelland net als elders in het land de komende jaren zal doorzetten, waarbij de daling bij de gespecialiseerde melkveebedrijven naar verwachting beduidend groter zal zijn als gevolg van een verhoging van de kritieke kostprijs in 
de afgelopen vier jaren met circa $10 \%$ vanwege extra milieu-investeringen. De grote gespecialiseerde varkensbedrijven hebben al volop maatregelen getroffen om te voldoen aan het ammoniak- en dierenwelzijnsbesluit voor 2020 en lijken klaar voor de toekomst. Een groot deel van de kleinere bedrijven met varkens in het oosten van Nederland heeft zich echter aangemeld voor de stoppersregeling en opschorting gekregen van de verplichte investeringen tot 2020. Deze bedrijven hebben eind 2019 hun stallen verplicht leeg moeten draaien of moesten proberen alsnog te voldoen aan de voorwaarden van het Besluit emissiearme huisvesting om voorlopig toch door te gaan met de varkenshouderij.

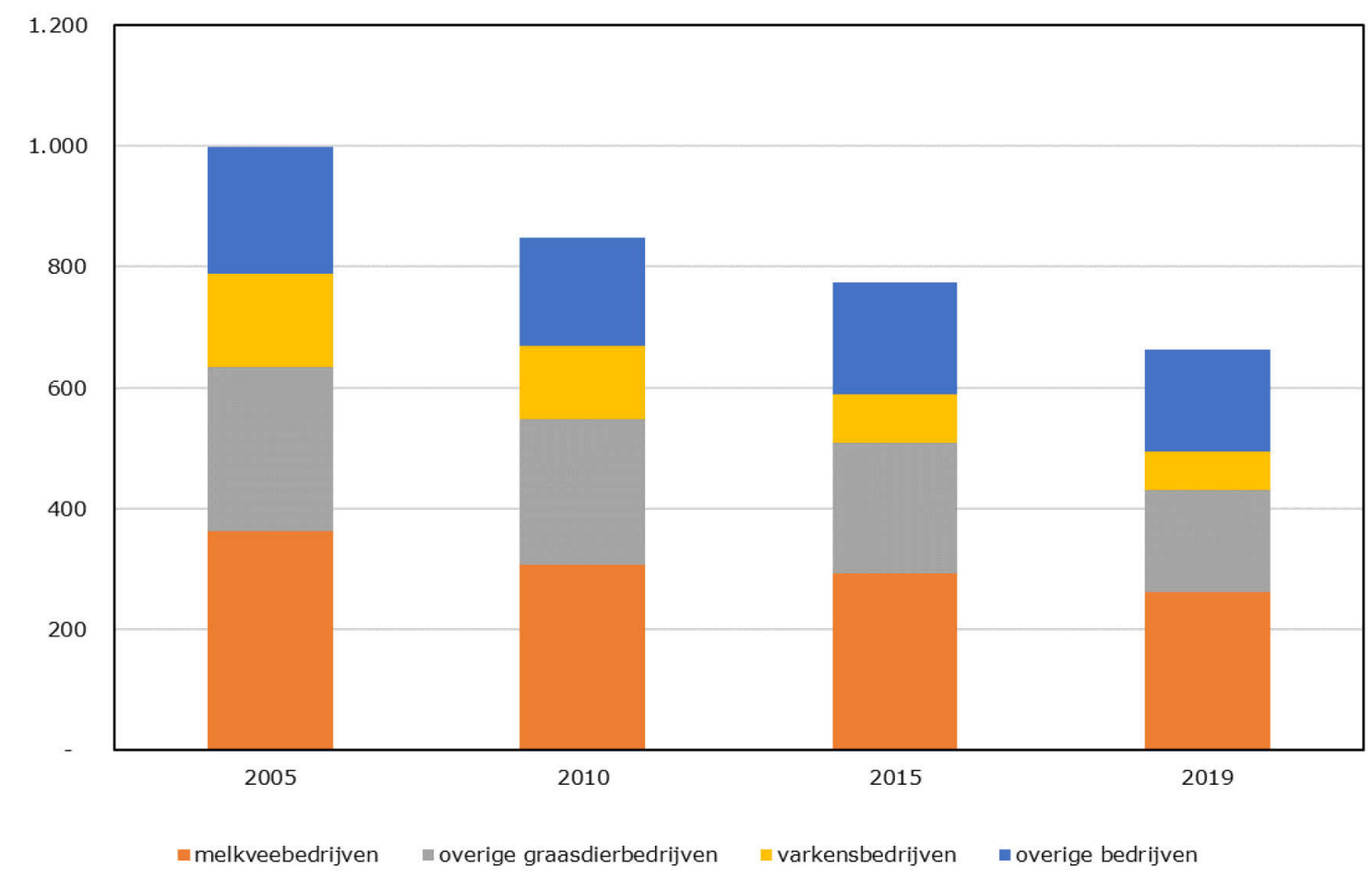

Figuur 3.1 Aantal agrarische bedrijven in Berkelland naar bedrijfstype, 2005-2019 Bron: CBS Landbouwtelling, bewerking Wageningen Economic Research.

Tabel 3.1 Aantal agrarische bedrijven in Berkelland naar bedrijfstype, 2005-2019.

\begin{tabular}{|c|c|c|c|c|c|}
\hline & 2005 & 2010 & 2015 & 2019 & $\begin{array}{r}\text { mutatie per } \\
\text { jaar }(\%)\end{array}$ \\
\hline Berkelland, totaal & 999 & 848 & 774 & 663 & $-2,89 \%$ \\
\hline overige graasdierbedrijven & 272 & 241 & 217 & 169 & $-3,34 \%$ \\
\hline varkensbedrijven & 154 & 123 & 81 & 63 & $-6,18 \%$ \\
\hline Achterhoek & 4.942 & 4.378 & 3.916 & 3.316 & $-2,81 \%$ \\
\hline Oost-Nederland & 25.988 & 23.160 & 20.707 & 17.399 & $-2,83 \%$ \\
\hline Nederland & 81.750 & 72.324 & 63.913 & 53.233 & $-3,02 \%$ \\
\hline
\end{tabular}

Bron: CBS Landbouwtelling, bewerking Wageningen Economic Research. 


\subsection{Areaal cultuurgrond}

In de periode 2005-2019 is het areaal cultuurgrond in Berkelland afgenomen van 20.300 naar 17.700 hectare. Deze daling van gemiddeld 0,95\% per jaar is beduidend groter dan de jaarlijkse daling van 0,45 tot $0,50 \%$ in de Achterhoek, Oost-Nederland en geheel Nederland (Figuur 3.2 en Tabel 3.2). Bij nadere bestudering blijkt de grootste daling in de gemeente Berkelland plaats te vinden tussen 2005 en 2007 met 1.100 hectare, en houdt de daling na 2007 gelijke tred met de Achterhoek en Oost-Nederland. Waarschijnlijk is dit de nasleep van de gemeentelijke herindeling op 1 januari 2005, waarbij de buurschappen Mariënvelde (voorheen gemeente Ruurlo) en Zwolle (voorheen gemeente Eibergen) werden toegevoegd aan de nieuwe gemeente Oost Gelre in plaats van Berkelland. Het areaal cultuurgrond in Oost Gelre is in diezelfde periode met 700 hectare gestegen. Andere mogelijke oorzaken voor de daling die werden genoemd zijn de onttrekking voor natuurgebieden, de aanleg van het Regionaal Bedrijvenpark Laarberg en de aankoop van grond ten behoeve van de nieuwe N18.

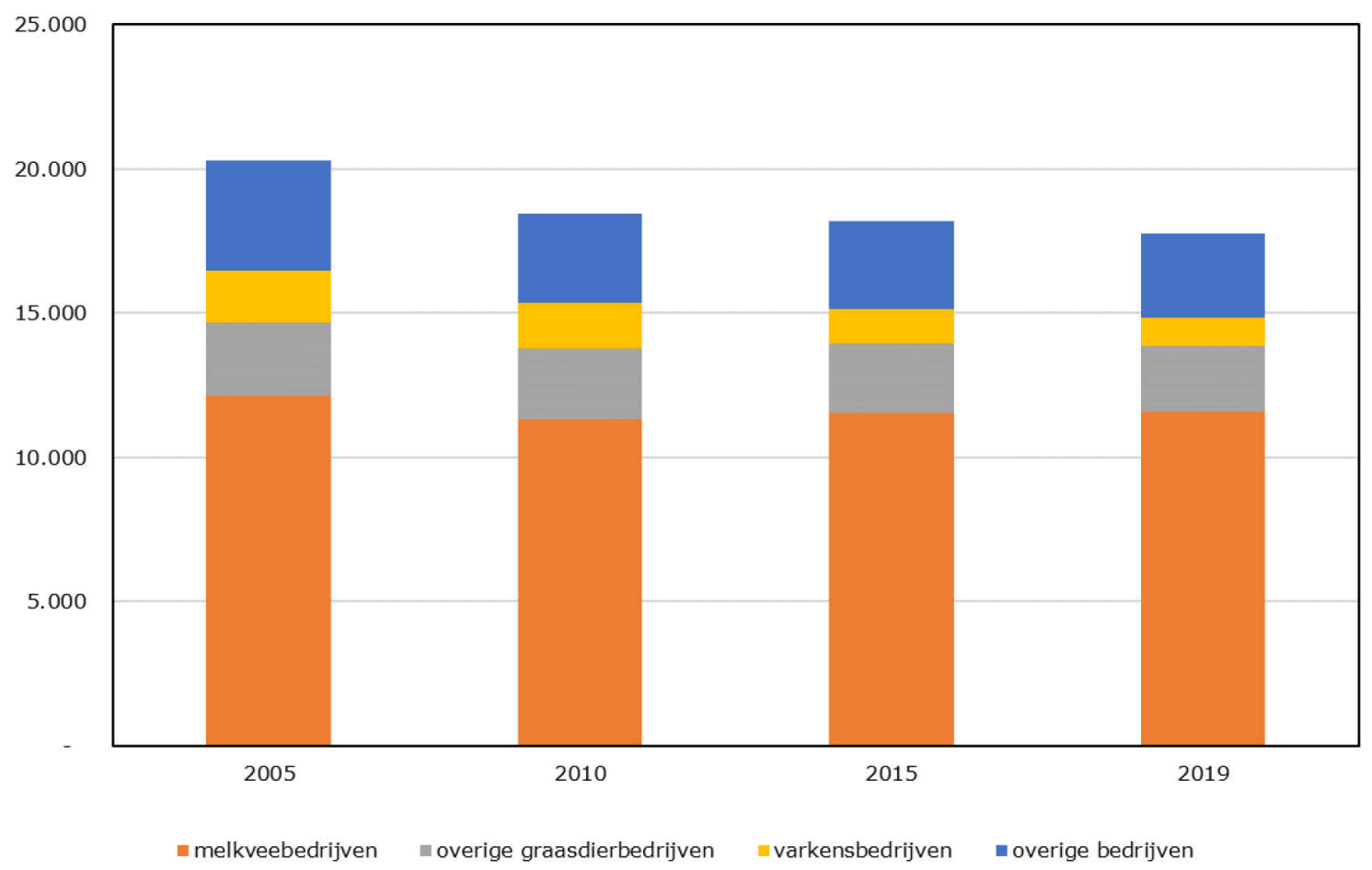

Figuur 3.2 Areaal cultuurgrond (in hectare) in Berkelland naar bedrijfstype, 2005-2019 Bron: CBS Landbouwtelling, bewerking Wageningen Economic Research.

Tabel 3.2 Areaal cultuurgrond (in hectare) in Berkelland naar bedrijfstype, 2005-2019.

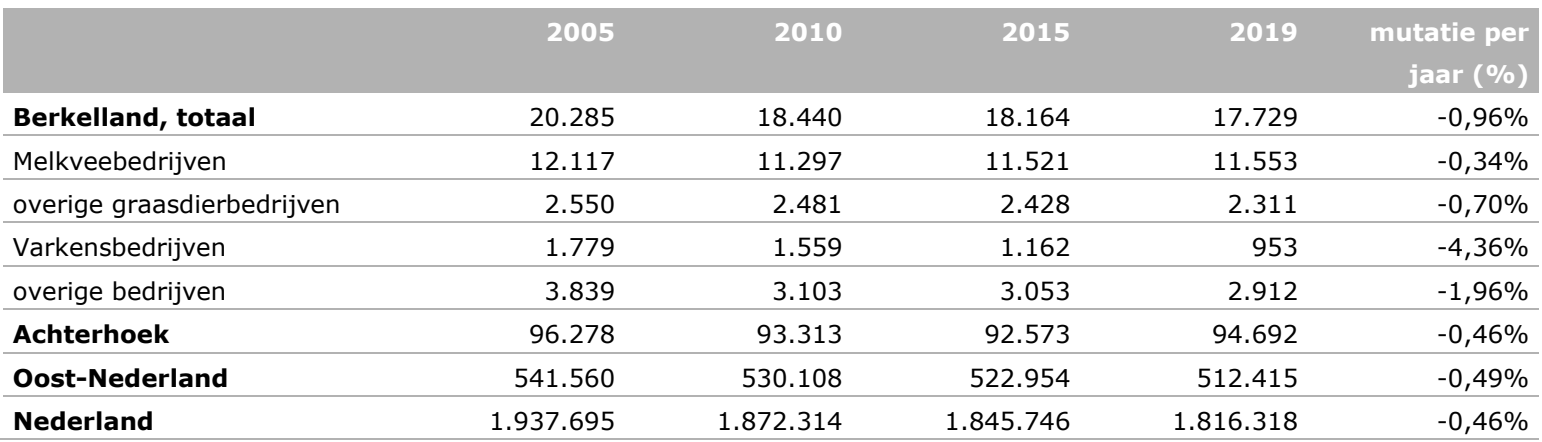

Bron: CBS Landbouwtelling, bewerking Wageningen Economic Research. 
In 2019 is twee derde van de cultuurgrond in gebruik bij melkveebedrijven; dat is gemiddeld 44 hectare per bedrijf (Figuur 3.3 en Tabel 3.3). De groep overige graasdierbedrijven gebruikt 13\% van de grond en dat komt overeen met gemiddeld 14 hectare per bedrijf. De gespecialiseerde varkens-bedrijven nemen slechts $5 \%$ van de grond voor hun rekening, maar hebben wel gemiddeld 15 hectare per bedrijf. De groep overige bedrijven heeft $16 \%$ van de cultuurgrond in gebruik en is per bedrijf gemiddeld 17 hectare groot. Het aandeel van de varkensbedrijven en overige bedrijven in het areaal cultuurgrond is sinds 2005 voortdurend afgenomen.

In de periode 2005-2019 is het areaal cultuurgrond per bedrijf gemiddeld over alle bedrijfstypen gestegen met 2,0\% per jaar en de gespecialiseerde melkvee- en varkensbedrijven wijken daarvan nauwelijks af. De bedrijven groeien wel beduidend minder hard dan in de rest van de Achterhoek en Nederland.

Volgens de informanten uit de agrarische accountancy en advies zullen de grote gespecialiseerde varkensbedrijven mede dankzij de hoge varkensprijzen als gevolg van de uitbraken van Afrikaanse varkenspest in China in 2019 de komende jaren naar verwachting extra grond aankopen om de financiële basis onder hun bedrijf te versterken, daarop voedergewassen te telen voor eigen gebruik en bovendien extra plaatsingsruimte te creëren voor de eigen mest. Het laatste effect zal overigens beperkt zijn, omdat ruwweg voor de mest van elke 5 zeugen of 25 biggen een hectare grond nodig is!

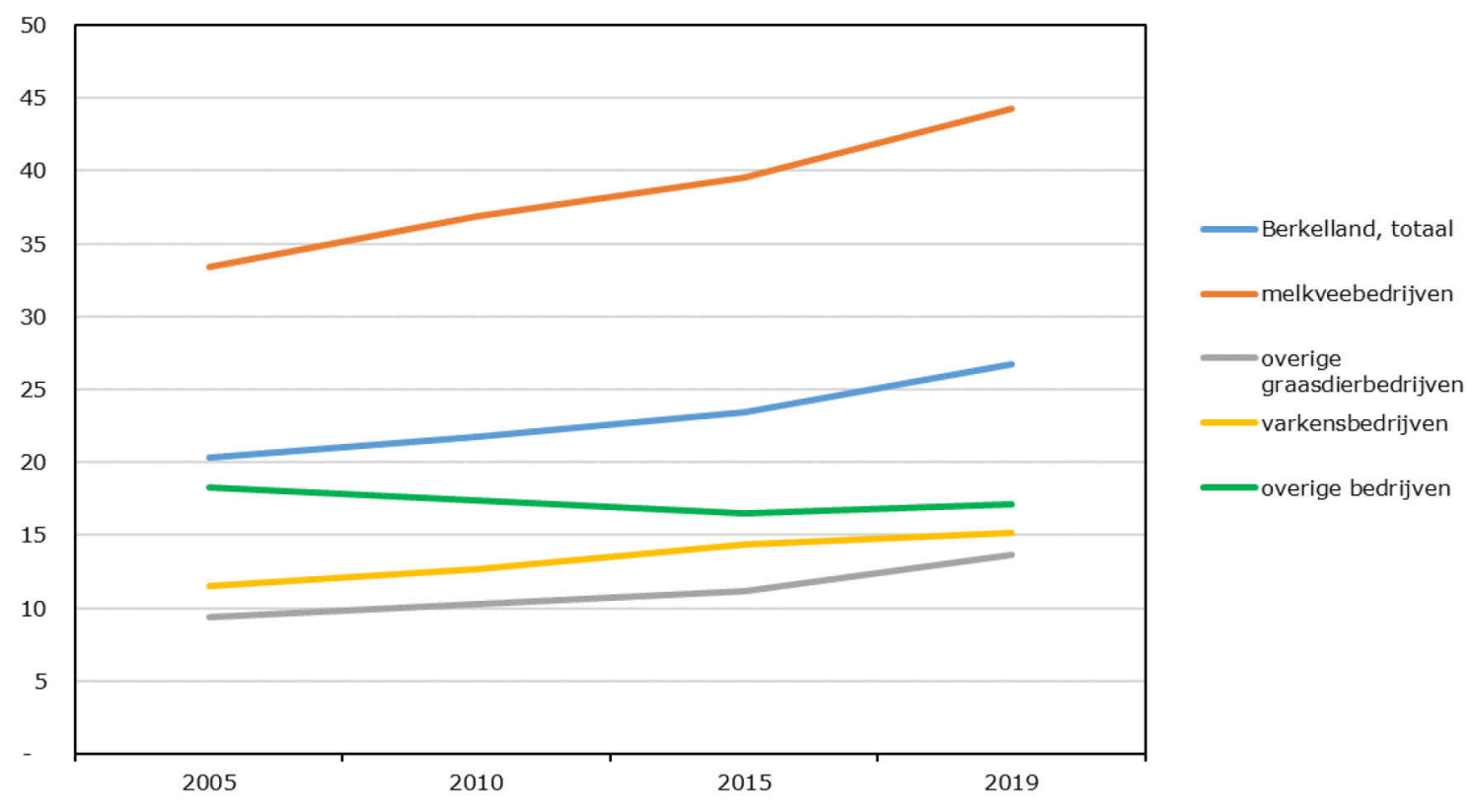

Figuur 3.3 Bedrijfsgrootte (in hectare) in Berkelland naar bedrijfstype, 2005-2019 Bron: CBS Landbouwtelling, bewerking Wageningen Economic Research.

Tabel 3.3 Bedrijfsgrootte (in hectare) in Berkelland naar bedrijfstype, 2005-2019.

\begin{tabular}{|c|c|c|c|c|c|}
\hline & 2005 & 2010 & 2015 & 2019 & $\begin{array}{r}\text { mutatie per } \\
\text { jaar }(\%)\end{array}$ \\
\hline Berkelland, totaal & 20 & 22 & 23 & 27 & $1,99 \%$ \\
\hline overige graasdierbedrijven & 9 & 10 & 11 & 14 & $2,73 \%$ \\
\hline varkensbedrijven & 12 & 13 & 14 & 15 & $1,95 \%$ \\
\hline Achterhoek & 20 & 22 & 25 & 29 & $2,42 \%$ \\
\hline Oost-Nederland & 21 & 23 & 25 & 29 & $2,41 \%$ \\
\hline Nederland & 24 & 26 & 29 & 34 & $2,64 \%$ \\
\hline
\end{tabular}

Bron: CBS Landbouwtelling, bewerking Wageningen Economic Research. 


\subsection{Veestapel}

De ontwikkeling van de veestapel in Berkelland in de periode 2005-2019 verschilt sterk per diersoort (Figuur 3.4 en Tabel 3.4). Het aantal melkkoeien is door de jaren heen vrij stabiel gebleven, maar het aantal varkens, paarden en schapen is met enkele procenten per jaar gedaald en het aantal pony's zelfs met bijna $10 \%$ per jaar. Daarentegen is het aantal geiten sinds 2005 ruimschoots verdubbeld tot 8.500 stuks, die merendeels te vinden zijn op de vijf gespecialiseerde geitenbedrijven. De pluimveestapel vertoont grote schommelingen; het gaat hierbij om een gering aantal bedrijven en de jaarlijkse Landbouwtelling is bovendien slechts een momentopname.

Bij de varkens is overigens het aantal zeugen sterker gedaald dan het aantal vleesvarkens; dit is ook een weerspiegeling van de sterkere daling van het aantal zeugenbedrijven dan van het aantal vleesvarkensbedrijven sinds 2005. Het aantal gesloten varkensbedrijven is minder gedaald en deze houden een toenemend aandeel van de varkens. Tot slot leidt ook de productiviteitsstijging van de zeugen (meer biggen per zeug) tot een hogere verhouding tussen het aantal vleesvarkens en zeugen.

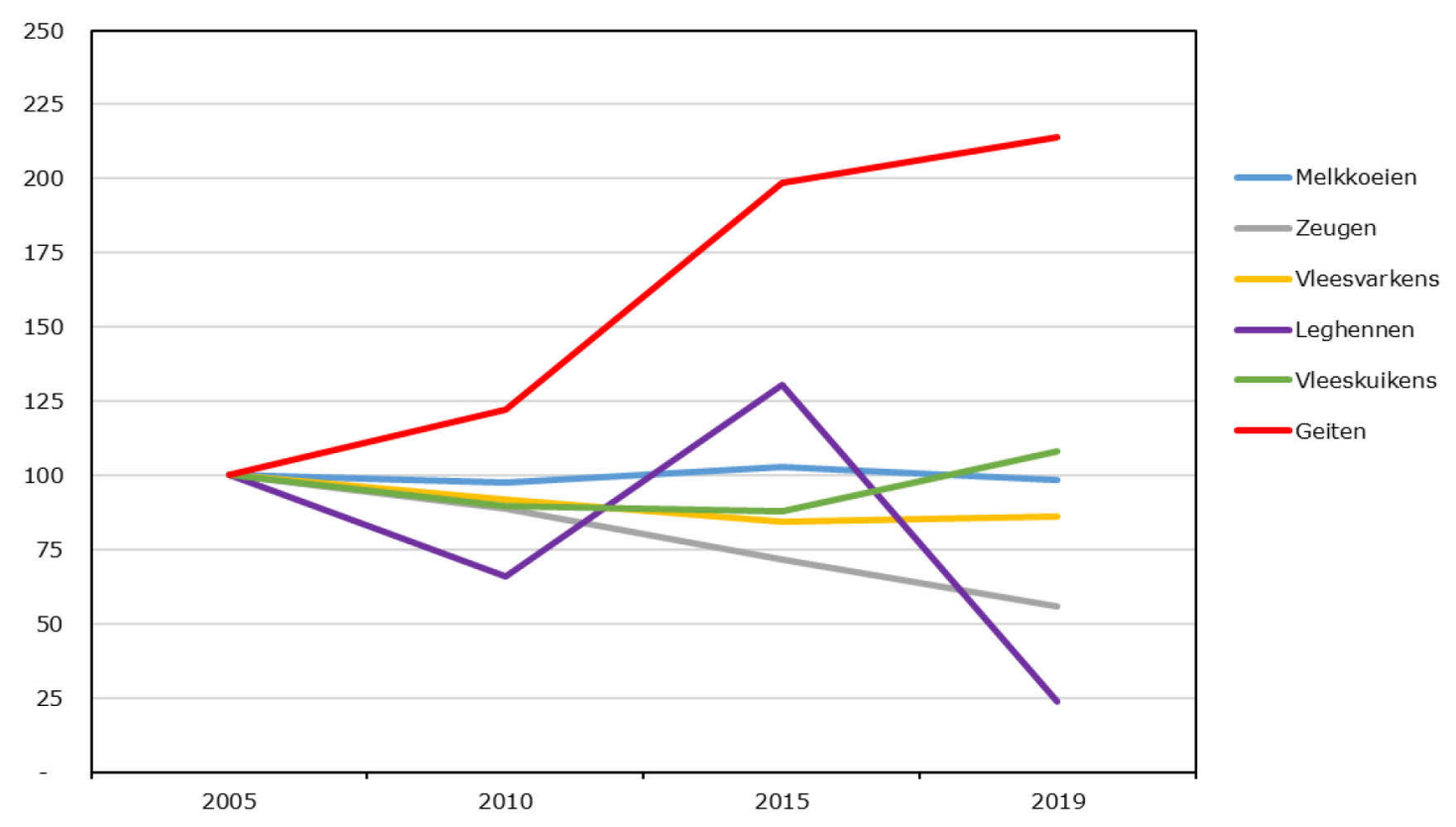

Figuur 3.4 Ontwikkeling aantal landbouwhuisdieren in Berkelland per diersoort, 2005-2019 $(2005=100)$

Bron: CBS Landbouwtelling, bewerking Wageningen Economic Research.

Tabel 3.4 Aantal landbouwhuisdieren in Berkelland, 2005-2019.

\begin{tabular}{|c|c|c|c|c|c|}
\hline & 2005 & 2010 & 2015 & 2019 & $\begin{array}{r}\text { mutatie per } \\
\text { jaar }(\%)\end{array}$ \\
\hline Melkkoeien & 25.416 & 24.797 & 26.163 & 25.009 & $-0,12 \%$ \\
\hline waarvan zeugen & 26.254 & 23.325 & 18.795 & 14.636 & $-4,09 \%$ \\
\hline vleesvarkens & 117.865 & 108.531 & 99.538 & 101.458 & $-1,06 \%$ \\
\hline Vleeskuikens & 303.307 & 271.541 & 266.097 & 328.011 & $0,56 \%$ \\
\hline Geiten & 3.967 & 4.853 & 7.882 & 8.488 & $5,58 \%$ \\
\hline Paarden & 1.435 & 1.186 & 968 & 798 & $-4,10 \%$ \\
\hline Pony's & 456 & 303 & 259 & 112 & $-9,54 \%$ \\
\hline
\end{tabular}

Bron: CBS Landbouwtelling, bewerking Wageningen Economic Research. 


\subsection{Arbeid}

In de periode 2005-2019 is de werkgelegenheid in de land- en tuinbouw in Berkelland afgenomen van 1.660 naar 1.250 arbeidsjaareenheden (aje). Deze daling van gemiddeld 2,0\% per jaar is beduidend groter dan de jaarlijkse daling van bijna $1,7 \%$ in de Achterhoek en rond de $1,0 \%$ in Oost-Nederland en Nederland als geheel (Figuur 3.5 en Tabel 3.5). Bij nadere bestudering blijkt ook hier dat de grootste daling in de gemeente Berkelland plaatsvindt voor 2010, mogelijk als gevolg van de gemeentelijke herindeling, en houdt de daling na 2010 gelijke tred met de rest van Nederland.

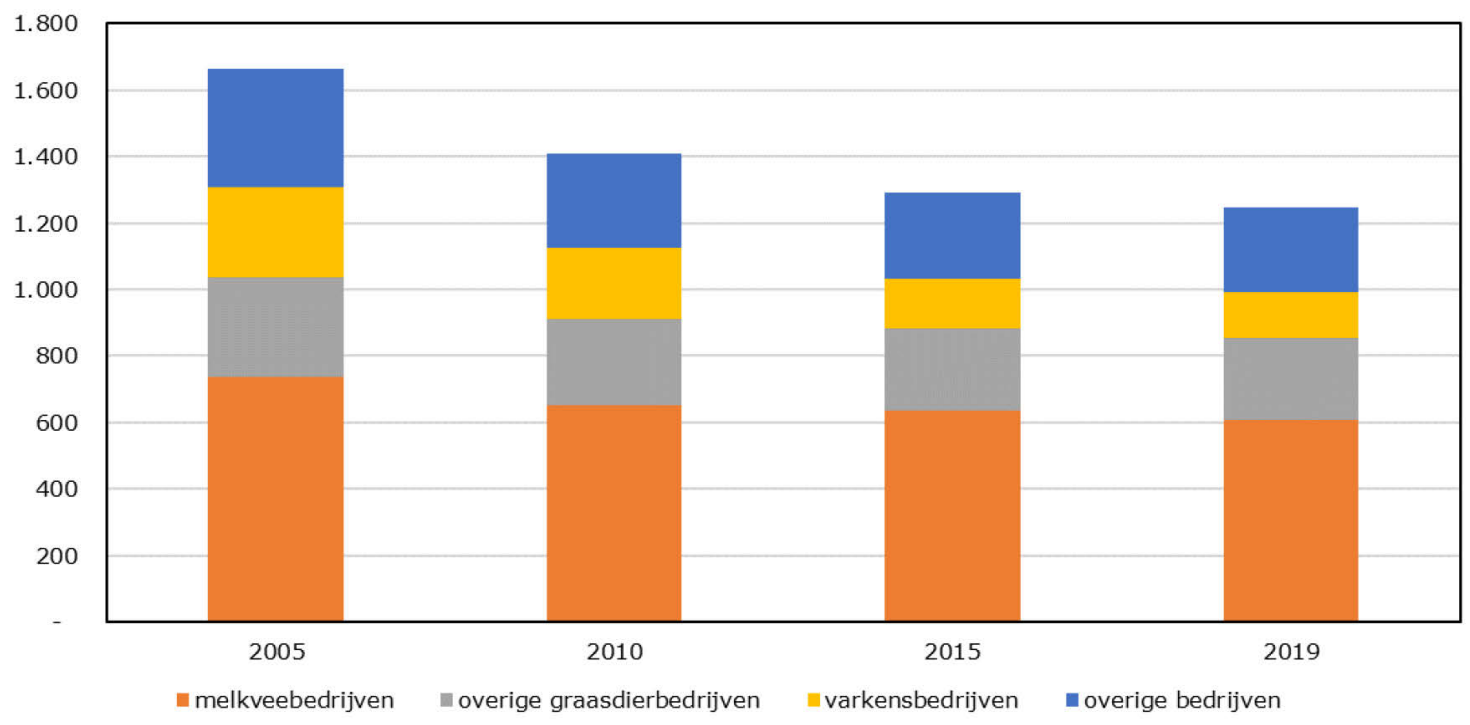

Figuur 3.5 Werkgelegenheid (in arbeidsjaren) in Berkelland naar bedrijfstype, 2005-2019 Bron: CBS Landbouwtelling, bewerking Wageningen Economic Research.

Tabel 3.5 Werkgelegenheid (in arbeidsjaren) in Berkelland naar bedrijfstype, 2005-2019.

\begin{tabular}{|c|c|c|c|c|c|}
\hline & 2005 & 2010 & 2015 & 2019 & $\begin{array}{r}\text { mutatie per } \\
\text { jaar }(\%)\end{array}$ \\
\hline Berkelland, totaal & 1.662 & 1.408 & 1.290 & 1.247 & $-2,03 \%$ \\
\hline overige graasdierbedrijven & 297 & 257 & 247 & 245 & $-1,37 \%$ \\
\hline varkensbedrijven & 271 & 217 & 150 & 136 & $-4,82 \%$ \\
\hline Achterhoek & 7.915 & 6.847 & 6.538 & 6.256 & $-1,67 \%$ \\
\hline Oost-Nederland & 45.345 & 42.266 & 39.203 & 38.781 & $-1,11 \%$ \\
\hline Nederland & 175.375 & 169.587 & 156.409 & 156.304 & $-0,82 \%$ \\
\hline
\end{tabular}

Bron: CBS Landbouwtelling, bewerking Wageningen Economic Research.

In 2019 werkt de helft van de arbeidskrachten in de land- en tuinbouw in Berkelland op melkveebedrijven; dat is gemiddeld 2,3 aje per bedrijf (Figuur 3.6 en Tabel 3.6). De groepen overige graas-dierbedrijven en overig bedrijven bieden elk werk aan ongeveer $20 \%$ van de arbeidskrachten en dat komt overeen met gemiddeld 1,5 aje per bedrijf. De gespecialiseerde varkensbedrijven nemen ruim $10 \%$ van de arbeidskrachten voor hun rekening en hebben gemiddeld 2,1 aje per bedrijf.

In de periode 2005-2019 is in Berkelland de arbeidsbezetting per bedrijf gemiddeld over alle bedrijfstypen gestegen met 0,9\% per jaar en op de gespecialiseerde melkvee- en varkensbedrijven met respectievelijk 1,0 en 1,45\% per jaar. De bedrijven groeien ook qua aantal arbeidskrachten minder hard dan in de rest van de Achterhoek en Nederland. 


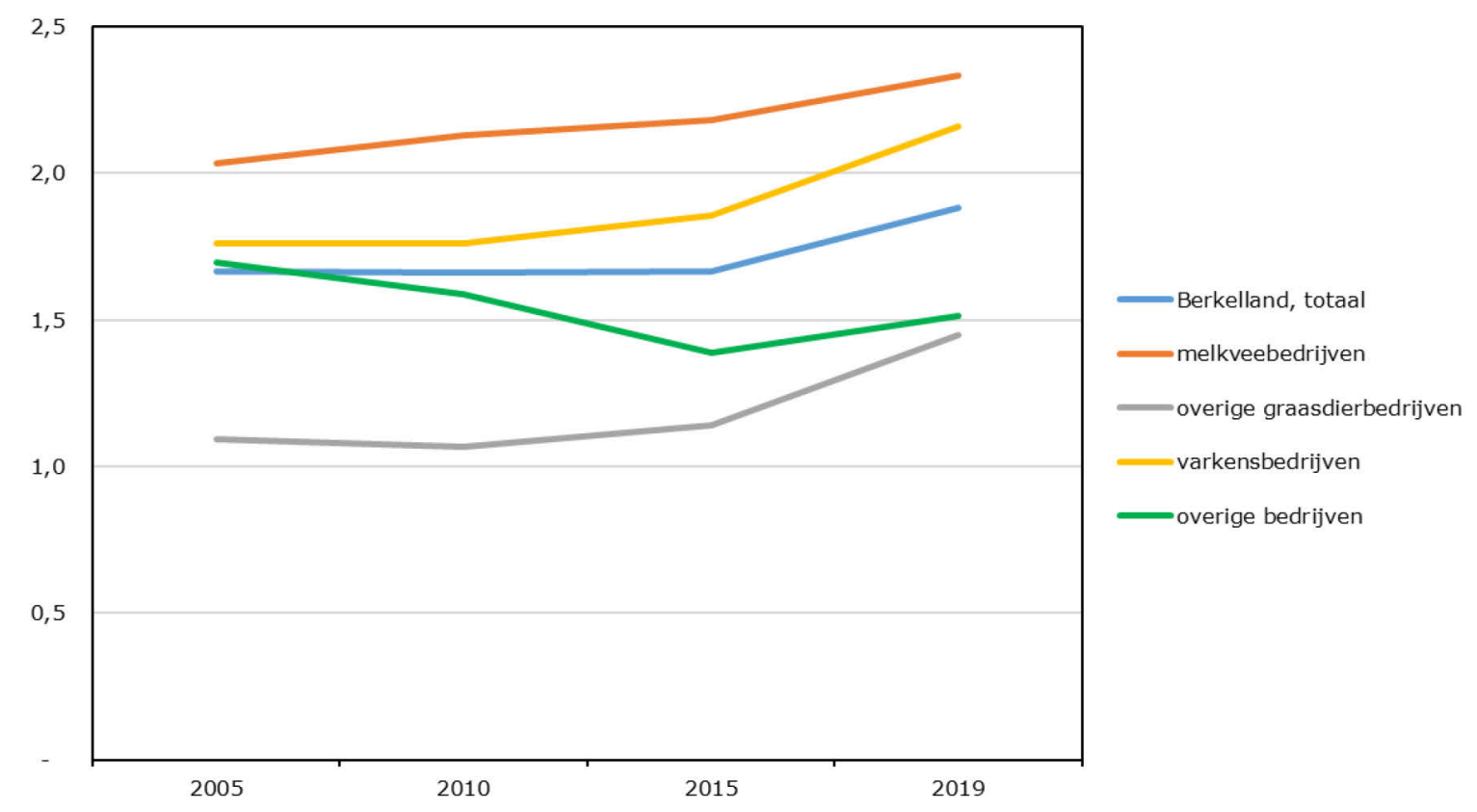

Figuur 3.6 Arbeidsbezetting per bedrijf (in arbeidsjaren) in Berkelland naar bedrijfstype, 2005-2019.

Bron: CBS Landbouwtelling, bewerking Wageningen Economic Research.

Tabel 3.6 Arbeidsbezetting per bedrijf (in arbeidsjaren) in Berkelland naar bedrijfstype, 2005-2019.

\begin{tabular}{|c|c|c|c|c|c|}
\hline & 2005 & 2010 & 2015 & 2019 & $\begin{array}{r}\text { mutatie per } \\
\text { jaar }(\%)\end{array}$ \\
\hline Berkelland, totaal & 1,7 & 1,7 & 1,7 & 1,9 & $0,88 \%$ \\
\hline overige graasdierbedrijven & 1,1 & 1,1 & 1,1 & 1,4 & $2,05 \%$ \\
\hline varkensbedrijven & 1,8 & 1,8 & 1,9 & 2,2 & $1,46 \%$ \\
\hline Achterhoek & 1,6 & 1,6 & 1,7 & 1,9 & $1,18 \%$ \\
\hline Oost-Nederland & 1,7 & 1,8 & 1,9 & 2,2 & $1,76 \%$ \\
\hline Nederland & 2,1 & 2,3 & 2,4 & 2,9 & $2,27 \%$ \\
\hline
\end{tabular}

Bron: CBS Landbouwtelling, bewerking Wageningen Economic Research.

\subsection{Standaardopbrengst}

De standaardopbrengst (SO) is een maat voor de gemiddelde omzet onder standaardomstandigheden. In de periode 2005-2019 is de standaardopbrengst in de land- en tuinbouw in Berkelland gestegen van 151 naar 182 miljoen euro. Deze groei van gemiddeld 1,35\% per jaar blijft achter bij de jaarlijkse stijging van $1,9 \%$ in de Achterhoek en geheel Nederland en 2,5\% in Oost-Nederland (Figuur 3.7 en Tabel 3.7). Bij nadere bestudering blijkt dat de kleinste groei in de gemeente Berkelland plaats vindt voor 2010, mogelijk als gevolg van de gemeentelijke herindeling, en houdt de stijging na 2010 gelijke tred met de Achterhoek en Oost-Nederland. 


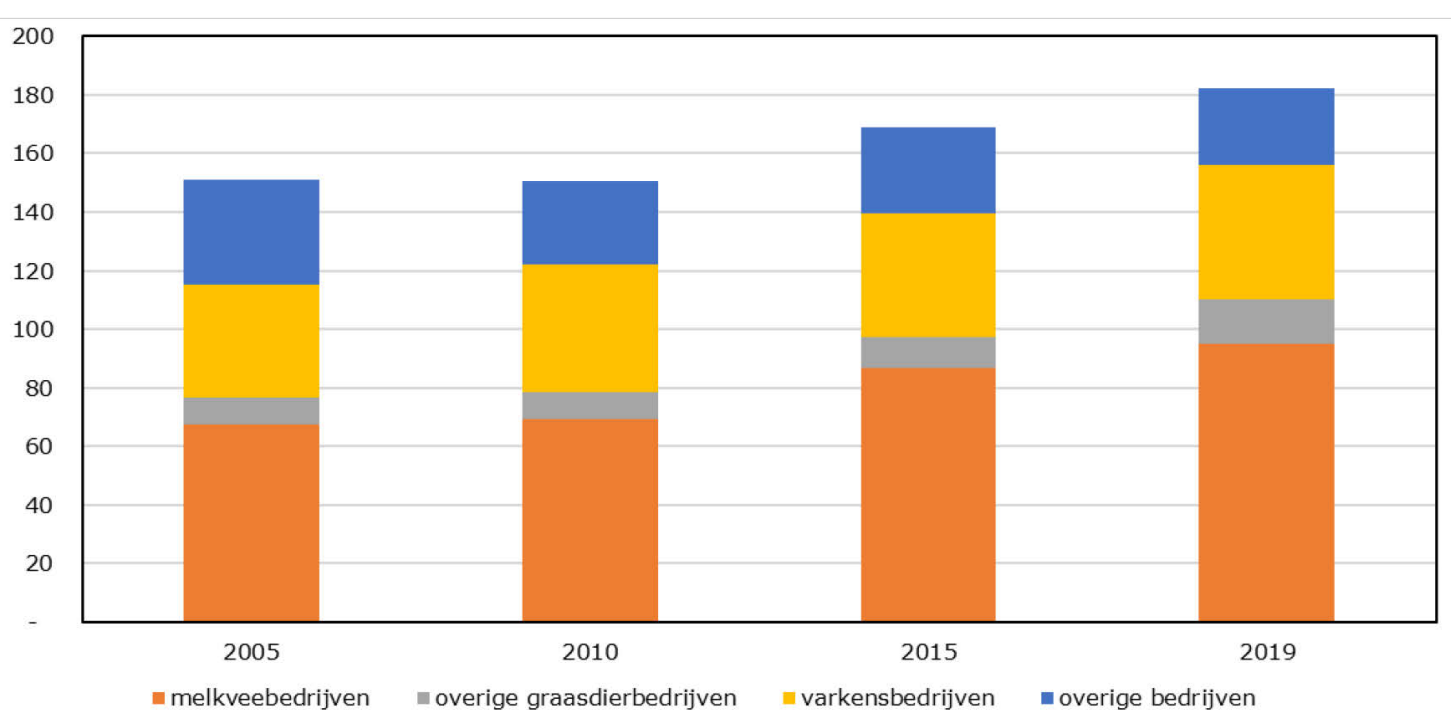

Figuur 3.7 Standaardopbrengst (in miljoen euro) in Berkelland naar bedrijfstype, 2005-2019 Bron: CBS Landbouwtelling, bewerking Wageningen Economic Research.

Tabel 3.7 Standaardopbrengst (in miljoen euro) in Berkelland naar bedrijfstype, 2005-2019.

\begin{tabular}{|c|c|c|c|c|c|}
\hline & 2005 & 2010 & 2015 & 2019 & $\begin{array}{r}\text { mutatie per } \\
\text { jaar }(\%)\end{array}$ \\
\hline Berkelland, totaal & 151 & 150 & 169 & 182 & $1,35 \%$ \\
\hline overige graasdierbedrijven & 10 & 9 & 11 & 15 & $3,37 \%$ \\
\hline varkensbedrijven & 38 & 43 & 42 & 46 & $1,35 \%$ \\
\hline Achterhoek & 691 & 717 & 816 & 899 & $1,89 \%$ \\
\hline Oost-Nederland & 4.367 & 4.878 & 5.413 & 6.161 & $2,49 \%$ \\
\hline Nederland & 18.314 & 19.607 & 21.434 & 23.878 & $1,91 \%$ \\
\hline
\end{tabular}

Bron: CBS Landbouwtelling, bewerking Wageningen Economic Research.

In 2019 wordt ruim de helft van de standaardopbrengst in de land- en tuinbouw in Berkelland gerealiseerd op melkveebedrijven; dat is gemiddeld 365.000 euro per bedrijf (Figuur 3.8 en Tabel 3.8). Het gemiddelde is vergelijkbaar met Oost-Nederland en $15 \%$ lager dan voor geheel Nederland. De gespecialiseerde varkensbedrijven nemen $25 \%$ van de standaardopbrengst voor hun rekening en realiseren gemiddeld ruim 730.000 euro per bedrijf. Het gemiddelde is hier eveneens vergelijkbaar met Oost-Nederland en $25 \%$ lager dan voor geheel Nederland. De groepen overige graasdierbedrijven en overige dragen respectievelijk $8 \%$ en $14 \%$ bij aan de standaardopbrengst en dat komt overeen met gemiddeld 85.000 en 160.000 euro per bedrijf.

In de periode 2005-2019 is in Berkelland de standaardopbrengst per bedrijf gemiddeld over alle bedrijfstypen gestegen met $4,7 \%$ per jaar en op de gespecialiseerde melkvee- en varkensbedrijven met respectievelijk 5,2 en 9,2\% per jaar. De gemiddelde standaardopbrengst per bedrijf is vergelijkbaar met de Achterhoek, maar beduidend kleiner dan in de rest van Nederland, als gevolg van het vrijwel ontbreken van (glas)tuinbouwbedrijven. Ook groeien de bedrijven qua standaardopbrengst minder hard dan in de rest van de Achterhoek en Nederland. 


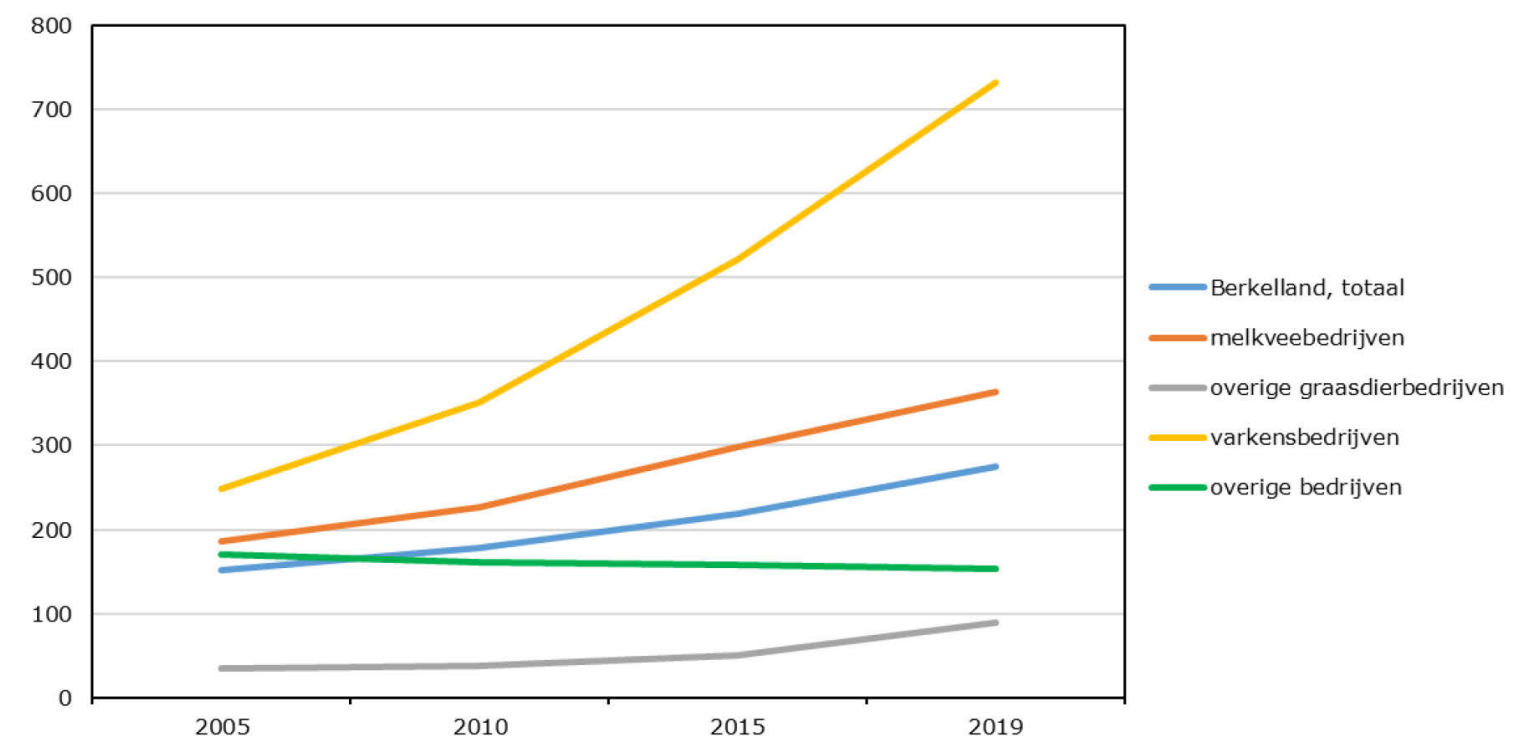

Figuur 3.8 Standaardopbrengst per bedrijf (in 1.000 euro) in Berkelland naar bedrijfstype, 20052019

Bron: CBS Landbouwtelling, bewerking Wageningen Economic Research.

Tabel 3.8 Standaardopbrengst per bedrijf (in 1.000 euro) in Berkelland naar bedrijfstype, 2005-2019.

\begin{tabular}{lrrrrr} 
& 2005 & 2010 & 2015 & 2019 & $\begin{array}{r}\text { mutatie per } \\
\text { jaar (\%) }\end{array}$ \\
Berkelland, totaal & 151 & 177 & 218 & 275 & $4,36 \%$ \\
\hline melkveebedrijven & 185 & 227 & 298 & 364 & $4,93 \%$ \\
\hline overige graasdierbedrijven & 35 & 38 & 50 & 90 & $6,94 \%$ \\
\hline varkensbedrijven & 248 & 351 & 522 & 733 & $8,03 \%$ \\
\hline overige bedrijven & 171 & 160 & 157 & 153 & $-0,80 \%$ \\
\hline Achterhoek & 140 & 164 & 208 & 271 & $4,84 \%$ \\
\hline Oost-Nederland & 168 & 211 & 261 & 354 & $5,47 \%$ \\
\hline Nederland & 224 & 271 & 335 & 449 & $5,08 \%$ \\
\hline
\end{tabular}

Bron: CBS Landbouwtelling, bewerking Wageningen Economic Research.

\subsection{Verdienvermogen}

In 2014 ontwikkelde Wageningen Economic Research een nieuw kengetal om beter inzicht te verschaffen in de toegevoegde waarde van een bedrijf dan alleen de standaardopbrengst. Dit is de zogenaamde standaardverdiencapaciteit (SVC) ofwel het vermogen om een inkomen te genereren onder standaard omstandigheden. Op melkveebedrijven is bijvoorbeeld de toegevoegde waarde groter dan op varkensbedrijven en is een groter deel van de omzet bestemd als een vergoeding voor de inzet van eigen arbeid en kapitaal.

In de periode 2010-2019 is de standaardverdiencapaciteit per bedrijf in de land- en tuinbouw in Berkelland gestegen van 36.000 naar 60.000 euro, een groei van gemiddeld 5,7\% per jaar (Figuur 3.9 en Tabel 3.9). Dit beeld is min of meer vergelijkbaar met de Achterhoek, maar de verdiencapaciteit en groei zijn wel kleiner dan in Oost-Nederland en Nederland als geheel door het vrijwel ontbreken van (glas)tuinbouwbedrijven. 
In 2019 kennen de melkvee- en varkensbedrijven een gemiddelde standaardverdiencapaciteit van ongeveer 95.000 euro per bedrijf. De groepen overige graasdierbedrijven en overige bedrijven hebben een beduidend lagere verdiencapaciteit van gemiddeld 18.000 en 31.000 euro per bedrijf. De zeer forse groei bij de overige graasdierbedrijven komt geheel voor rekening van de vijf gespecialiseerde geitenbedrijven.

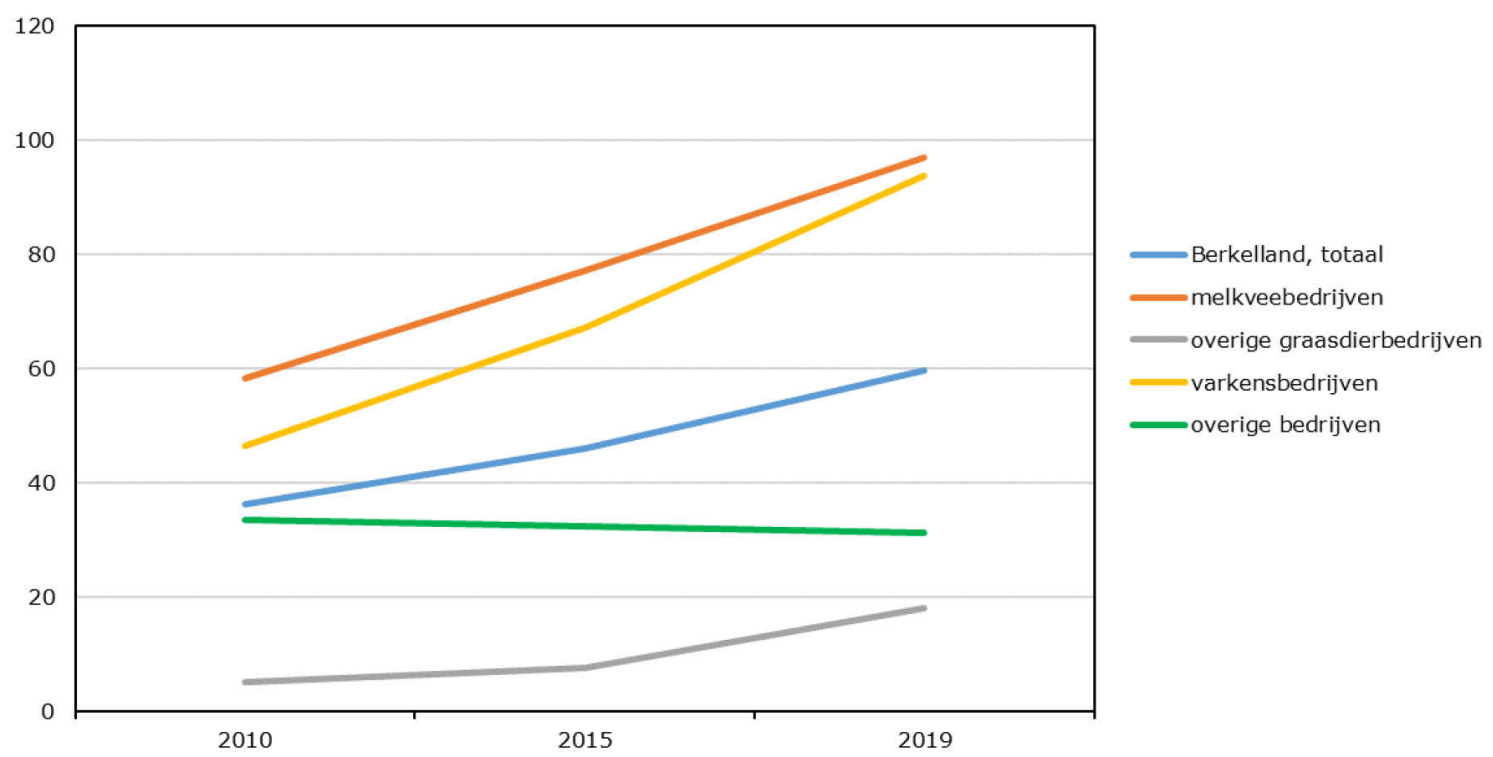

Figuur 3.9 Standaardverdiencapaciteit per bedrijf (in 1.000 euro) in Berkelland naar bedrijfstype, 2005-2019

Bron: CBS Landbouwtelling, bewerking Wageningen Economic Research.

Tabel 3.9 Standaardverdiencapaciteit per bedrijf (in 1.000 euro) in Berkelland naar bedrijfstype, 2010-2019.

\begin{tabular}{lrrrr} 
& 2010 & 2015 & 2019 & $\begin{array}{r}\text { mutatie per jaar } \\
(\%)\end{array}$ \\
\hline Berkelland, totaal & 36 & 46 & 60 & $5,70 \%$ \\
\hline melkveebedrijven & 58 & 77 & 97 & $5,82 \%$ \\
\hline overige graasdierbedrijven & 5 & 8 & 18 & $15,11 \%$ \\
\hline varkensbedrijven & 47 & 67 & 94 & $8,11 \%$ \\
\hline overige bedrijven & 33 & 33 & 61 & $-0,76 \%$ \\
\hline Achterhoek & 36 & 61 & 85 & $6,03 \%$ \\
\hline Oost-Nederland & 49 & 86 & 120 & $6,35 \%$ \\
\hline Nederland & 68 & $67,45 \%$ \\
\hline
\end{tabular}

Bron: CBS Landbouwtelling, bewerking Wageningen Economic Research.

Wellicht nog belangrijker dan het gemiddelde is de spreiding van de verdiencapaciteit per bedrijf over de bedrijfstypen en daarbinnen. In Figuur 3.10 wordt die spreiding geïllustreerd voor de jaren 2010 en 2018 (voor 2019 nog niet beschikbaar), waarbij vijf klassen zijn aangehouden. Van alle bedrijven in Berkelland in 2018 realiseert de helft een verdiencapaciteit van minder dan 35.000 euro, een niveau dat overeenkomt met een modaal inkomen per arbeidsjaar volgens het Centraal Planbureau. Deze bedrijven halen dus normaal gesproken geen volwaardig inkomen uit het bedrijf, zeker niet als meer dan een gezin hiervan moet rondkomen. De grootste problemen zitten echter in de groep overige graasdierbedrijven en overige bedrijven, waarin naar verwachting veel deeltijdboeren en potentiële stoppers zullen zitten. Bij de gespecialiseerde melkvee- en varkensbedrijven is tussen 2010 en 2018 een forse verbetering in verdiencapaciteit te zien, waardoor het percentage bedrijven met een verdiencapaciteit groter dan 70.000 euro (twee keer modaal) flink is toegenomen. Binnen de groep 
overige graasdierbedrijven hebben vooral de geitenbedrijven een verdiencapaciteit groter dan 70.000 euro en binnen de groep overige bedrijven geldt dat voor de meeste pluimveebedrijven.

In de periode 2014-2018 is de kostprijs van melk met 4 cent gestegen door extra investeringen als gevolg van de invoering van grondgebonden fosfaatrechten. Deze stijging is nog niet verdisconteerd in de berekening van de standaardverdiencapaciteit van melkveebedrijven in 2018, waardoor het beeld voor dat jaar te rooskleurig is. De verwachting van de geraadpleegde bedrijfsadviseurs is dat in 2018 in werkelijkheid ongeveer $30 \%$ van de melkveebedrijven een verdiencapaciteit kleiner dan 50.000 euro heeft en dat sluit ook beter aan bij de kritieke melkprijsmonitor van Flynth voor 2018.

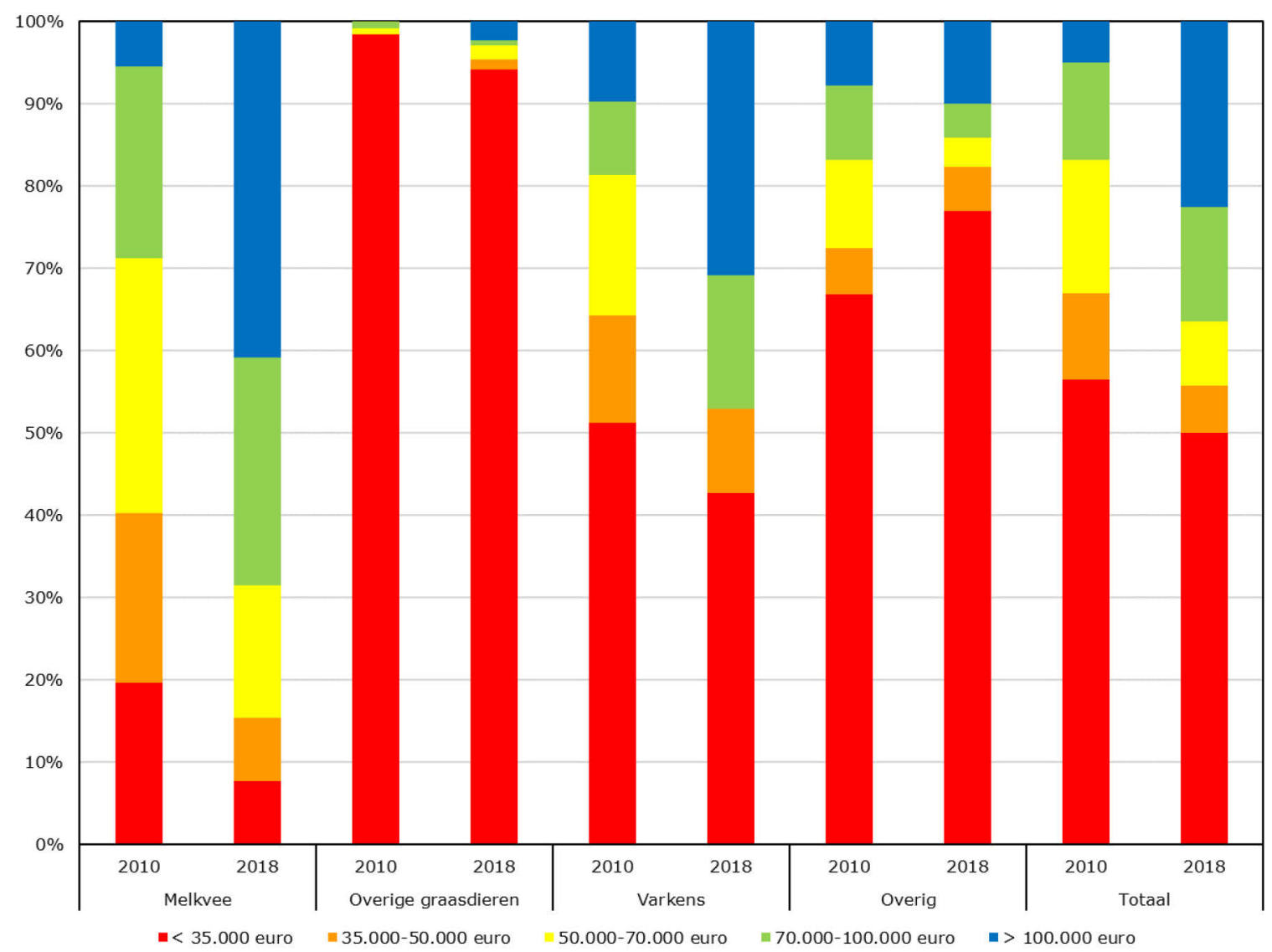

Figuur 3.10 Spreiding van de standaardverdiencapaciteit per bedrijf (in 1.000 euro) in Berkelland naar bedrijfstype, 2010 en 2018

Bron: CBS Landbouwtelling, bewerking Wageningen Economic Research.

\subsection{Opvolgingssituatie}

Bij de CBS Landbouwtelling wordt eens per vier jaar gevraagd naar de opvolgingssituatie op bedrijven met personenvennootschapen met een bedrijfshoofd van 51 jaar of ouder, voor het laatst in 2016.

In Figuur 3.11 wordt de opvolgingssituatie geïllustreerd op de land- en tuinbouwbedrijven in Berkelland in 2012 en 2016, waarbij een onderscheid wordt gemaakt naar diverse bedrijfstypen.

Het aandeel rechtspersonen in Berkelland is met ongeveer $2 \%$ gering in vergelijking met geheel Nederland, omdat in deze gemeente grote agrarische bedrijven als in de tuinbouw met overwegend 
een BV als rechtsvorm vrijwel ontbreken. Overigens zijn de zogenaamde hybride BV's ${ }^{1}$ niet zichtbaar in deze statistieken.

Bij de bedrijven met personenvennootschappen is het aandeel bedrijven met een bedrijfshoofd van 51 jaar of ouder gestegen van $64 \%$ naar $69 \%$, een vergrijzing die aansluit bij de brede maatschappelijke ontwikkeling als gevolg van het verhogen van de pensioenleeftijd. Die verhoging komt met name voor rekening van de bedrijven zonder opvolgers.

Gemiddeld over 2012 en 2016 was het aandeel bedrijven met een bedrijfshoofd van 51 jaar of ouder zonder opvolger met $27 \%$ het kleinst bij de melkveebedrijven, gevolgd door de varkensbedrijven met $38 \%$ en overige bedrijven met $43 \%$. Binnen laatstgenoemde groep hebben met name akkerbouwbedrijven met vooral voedergewassen het vaakst geen opvolger. Bij de groep overige graasdierbedrijven is het aandeel bedrijven zonder opvolger met $60 \%$ verreweg het hoogst. Binnen deze groep hebben met name de schapenbedrijven en overige rundveebedrijven geen opvolgers, maar hebben de geitenbedrijven daarentegen vaker jonge bedrijfshoofden en is opvolging nog geen issue.

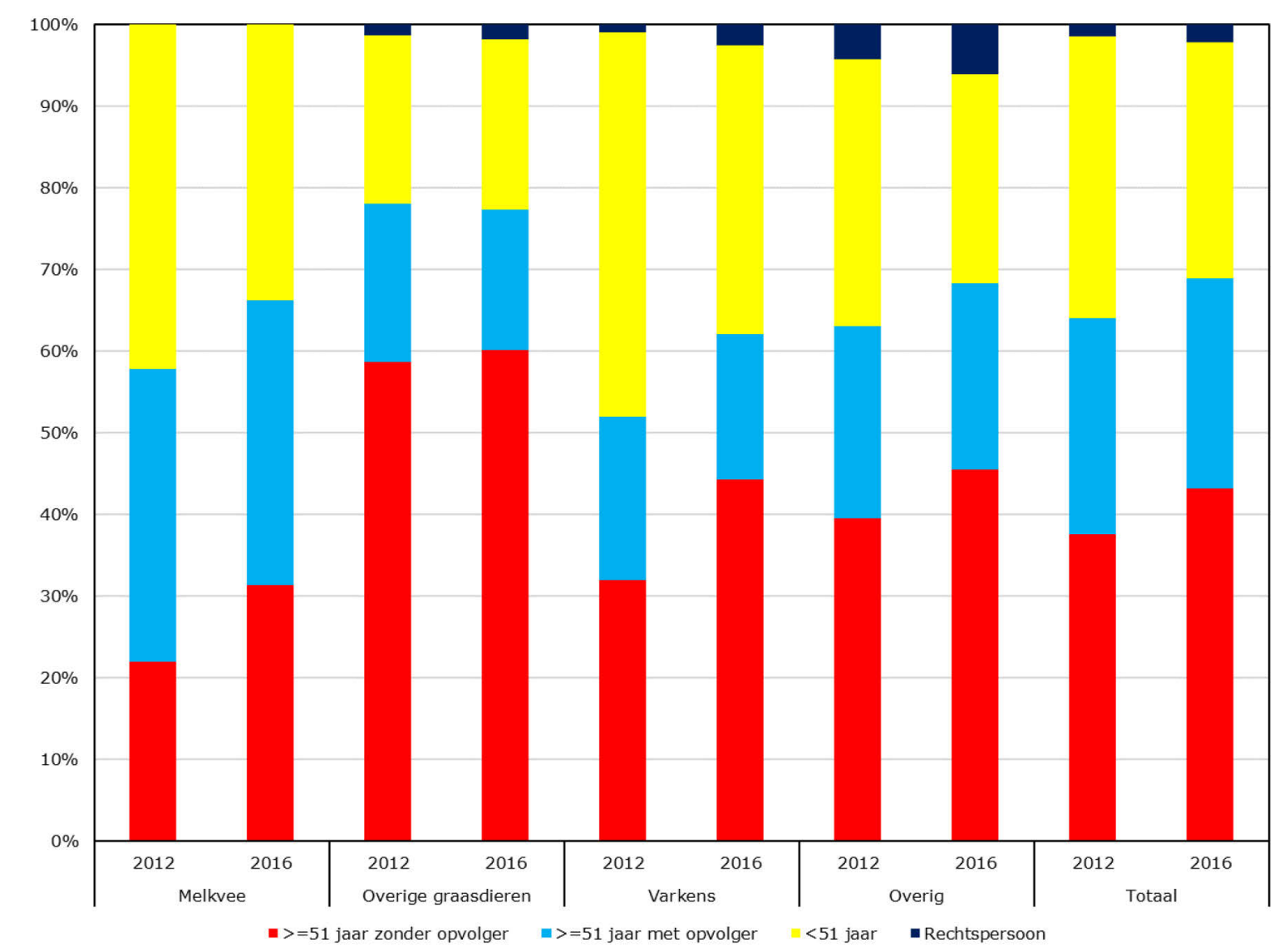

Figuur 3.11 Opvolgingssituatie in Berkelland naar bedrijfstype, 2012 en 2016 Bron: CBS Landbouwtelling, bewerking Wageningen Economic Research.

Het beeld van de standaardverdiencapaciteit in Figuur 3.10 en de opvolgingssituatie in Figuur 3.11 vertoont overigens opvallend veel overeenkomsten. Het aandeel bedrijven zonder volwaardig inkomen in 2016 op basis van de standaardverdiencapaciteit van 50\% komt bovendien redelijk overeen met het aandeel van $43 \%$ van bedrijven met een bedrijfshoofd van 51 jaar of ouder zonder opvolger.

\footnotetext{
${ }^{1}$ Bij een hybride BV is de besloten vennootschap één van de vennoten in een maatschap of vennootschap onder firma, waardoor kan worden geprofiteerd van de verschillende belastingregimes voor personenvennootschappen en rechtspersonen. Bij het onderbrengen van een $\mathrm{BV}$ onder een personenvennootschap hoeft ook geen $20 \%$ afroming van productierechten plaats te vinden.
} 


\subsection{Biologische landbouw}

Het aantal biologische bedrijven in Berkelland is al sinds 2005 stabiel op 6 of 7 bedrijven. Het aandeel biologisch in het totaal aantal bedrijven is hierdoor geleidelijk toegenomen van 0,7 naar 0,9\%, maar het aandeel biologisch in het totale areaal cultuurgrond blijft steken op rond de 0,5\%. Deze percentages liggen beduidend lager dan voor heel Nederland. In 2019 was de helft van de biologische bedrijven een varkensbedrijf. Biologische melkveebedrijven komen in Berkelland niet voor.

De verwachting is dat de biologische landbouw in Berkelland de komen jaren niet of nauwelijks zal uitbreiden. De volkscultuur in agrarisch Berkelland staat er niet echt voor open en bovendien is biologische teelt op zandgrond erg lastig uit het oogpunt van bodem- en onkruidbeheer. Belangrijker nog is het gebrek aan goede afzetmogelijkheden. Voor een lokale en regionale afzet van enige omvang zijn er voldoende grote woonkernen met geïnteresseerde consumenten in de buurt nodig. Ook de afstand naar grootschalige verwerkers van bijvoorbeeld biologische melk is groot. Mogelijk biedt dit segment wel tijdelijk ruimte voor oudere varkenshouders, die niet meer kunnen of willen investeren in bedrijfsuitbreiding.

\section{$3.9 \quad$ Verbreding}

Bij de CBS Landbouwtelling in 2016 is ook gevraagd naar eventuele multifunctionele activiteiten op het bedrijf. In Berkelland hield $21 \%$ van de land- en tuinbouwbedrijven zich bezig met verbreding, ofwel met bedrijfsmatige activiteiten anders dan landbouw (Figuur 3.12). Deze activiteiten betreffen vooral natuurbeheer (7\%), duurzame energieproductie voor eigen bedrijf (6\%), loonwerk (4\%), recreatie $(3 \%)$, verkoop van producten $(3 \%)$ en stalling van bijvoorbeeld caravans (2\%). Voor heel Nederland ligt het aandeel bedrijven met multifunctionele activiteiten 7 procentpunten hoger. Het verschil zit vooral in een hoger aandeel bedrijven dat aan natuurbeheer, loonwerk, huisverkoop en stalling doet.

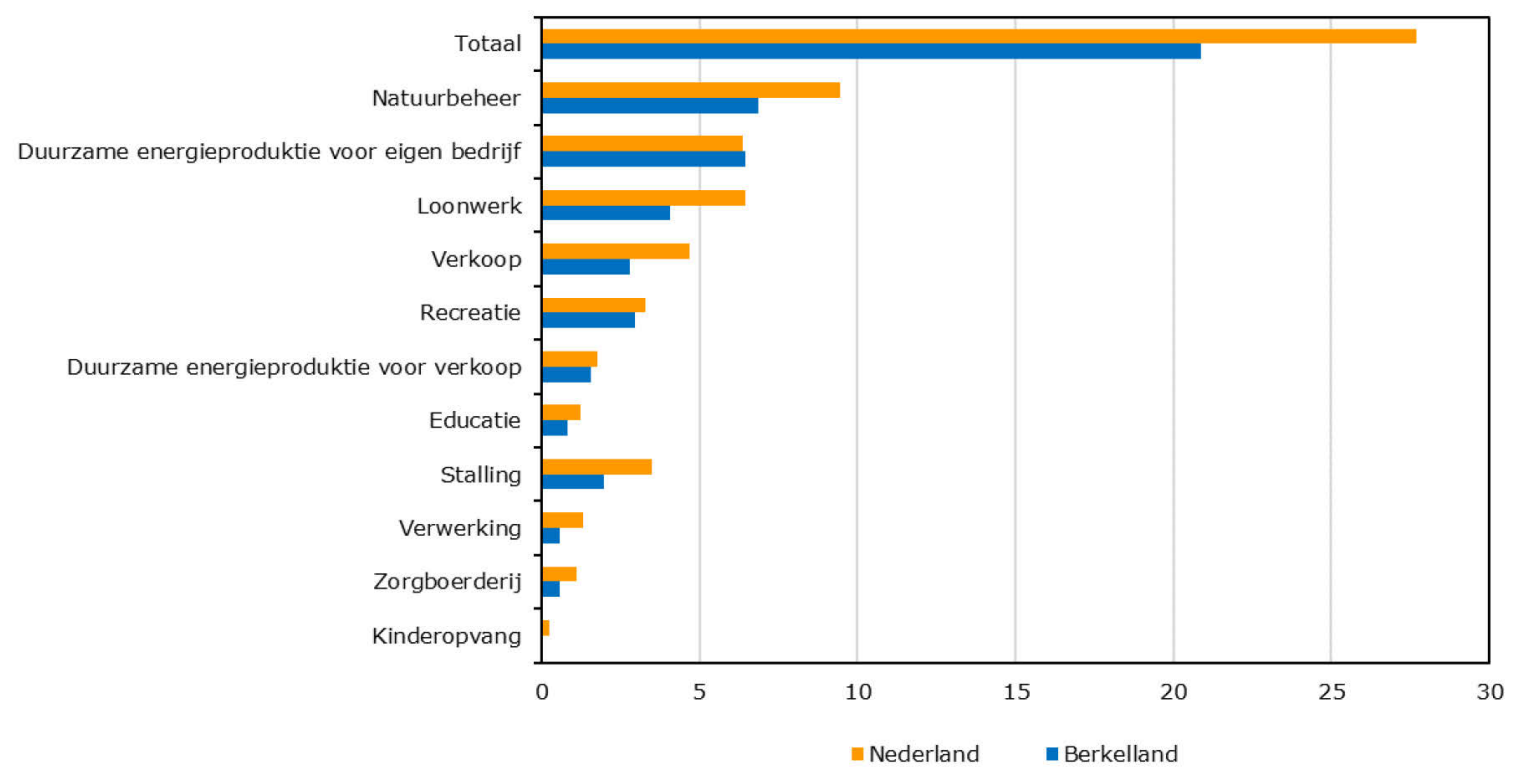

Figuur 3.12 Aandeel bedrijven met multifunctionele activiteiten in Berkelland en Nederland, 2016 Bron: CBS Landbouwtelling, bewerking Wageningen Economic Research. 


\section{Literatuur en websites}

Bouhuijs-Bos, I., S. Doove, A. Hendriks, K. Keller, P. Padding, S. Ströfer, G. Trouborst en M. Zuidema, 2018. Landelijke Informatievoorziening Vastgoedgebruik; Praktijktoetsen Leegstand. Rapport 180629, CBS Den Haag.

Everdingen, W. van, en A. Wisman, 2018. NSO-typering 2018; Normen en uitgangspunten bij typering van agrarische bedrijven in Nederland. Nota 2018-117, Wageningen Economic Research, Wageningen.

Gies, E., A. van Doorn en B. Bos, 2019. Mogelijke toekomstbeelden natuurinclusieve landbouw; Uitwerking van toekomstbeelden ten behoeve van de transitieopgave naar natuurinclusieve landbouw. Rapport 2957, Wageningen Environmental Research, Wageningen.

Gies, E., R. Smidt, R. van Och en I. Vleemingh, 2015. Nadere analyse vrijkomende agrarische bebouwing Gelderland. Alterra-rapport 2632, Alterra Wageningen UR (University \& Research centre), Wageningen.

Gies, E., A. van Doorn en B. Bos, 2019. Mogelijke toekomstbeelden natuurinclusieve landbouw; Uitwerking van toekomstbeelden ten behoeve van de transitieopgave naar natuurinclusieve landbouw. Rapport 2957, Wageningen Environmental Research, Wageningen.

Gies, E., W. Nieuwenhuizen en R. Smidt, 2014. Vrijkomende agrarische bebouwing in het landelijk gebied. Rapport 14.2.325, InnovatieNetwerk, Utrecht.

Hogenkamp Agrarische Coaching, 2019. Agrarische sector Berkelland naar de volgende fase; Een onderzoek naar de huidige situatie op het platteland van Gemeente Berkelland

Hoste, R., M. van Galen, R. Jongeneel, A. González Martinez en C. Wattel, 2018. Prijsontwikkeling van varkensrechten. Notitie 2018-112a, Wageningen Economic Research, Wageningen.

Riesmeijer, E., W. Pasman en P. Hogenkamp, 2017. Onderzoeksrapportage uitkomsten keukentafelgesprekken varkenshouders in de gemeente Berkelland. Concept-rapport Stimuland en Paulien Hogenkamp Agrarisch Consult \& Coaching. 


\section{Bijlage 1 NSO-typering voor Berkelland}

Tabel B1.1 Aantal bedrijven per NSO-bedrijfstype in de gemeente Berkelland in 2019 met indeling in clusters

\begin{tabular}{|c|c|c|}
\hline Cluster & NSO type naam & Aantal bedrijven \\
\hline Melkveebedrijven & Melkveebedrijven & 261 \\
\hline \multirow[t]{7}{*}{ Overige graasdierbedrijven } & Geitenbedrijven & 5 \\
\hline & Graasdierbedrijven met vooral voedergewassen & 16 \\
\hline & Overige graasdierbedrijven & 7 \\
\hline & Overige rundveebedrijven & 99 \\
\hline & Paard- en ponybedrijven & 17 \\
\hline & Schapenbedrijven & 13 \\
\hline & Vleeskalverenbedrijven & 12 \\
\hline \multirow[t]{3}{*}{ Varkensbedrijven } & Fokzeugenbedrijven & 14 \\
\hline & Vleesvarkensbedrijven & 35 \\
\hline & Overige varkensbedrijven & 14 \\
\hline \multirow[t]{19}{*}{ Overige bedrijven } & Akkerbouwbedrijven met vooral voedergewassen & 61 \\
\hline & Akkerbouw-graasdiercombinaties & 12 \\
\hline & Akkerbouwgroentebedrijven & 4 \\
\hline & Boomkwekerijbedrijven & 7 \\
\hline & Fruitbedrijven & 1 \\
\hline & Gewascombinaties & 2 \\
\hline & Glasgroentebedrijven & 1 \\
\hline & Graan-, oliezaad- en eiwitgewasbedrijven & 3 \\
\hline & Opengrondsgroentenbedrijven & 1 \\
\hline & Overige akkerbouwbedrijven & 34 \\
\hline & Overige blijvende teeltbedrijven & 1 \\
\hline & Overige gewas/veecombinaties & 5 \\
\hline & Overige glastuinbouwbedrijven & 1 \\
\hline & Overige hokdierbedrijven & 2 \\
\hline & Overige pluimveebedrijven & 3 \\
\hline & Veeteeltcombinatie, vooral graasdieren & 11 \\
\hline & Veeteeltcombinatie, vooral hokdieren & 11 \\
\hline & Vleeskuikenbedrijven & 5 \\
\hline & Zetmeelaardappelbedrijven & 5 \\
\hline Totaal & & 663 \\
\hline
\end{tabular}

Bron: CBS Landbouwtelling, bewerking Wageningen Economic Research. 


\section{Bijlage 2 Statistieken gespecialiseerde melkvee- en varkensbedrijven}

Tabel B2.1 Aantal melkkoeien, aantal melkveebedrijven en aantal melkkoeien per gespecialiseerd melkveebedrijf, 2005-2019

\begin{tabular}{|c|c|c|c|c|c|}
\hline & 2005 & 2010 & 2015 & 2019 & $\begin{array}{r}\text { mutatie per } \\
\text { jaar }(\%)\end{array}$ \\
\hline \multicolumn{6}{|c|}{ Totaal aantal melkkoeien } \\
\hline Berkelland & 21.109 & 21.417 & 23.342 & 22.920 & $0,59 \%$ \\
\hline Achterhoek & 99.519 & 106.323 & 119.250 & 114.867 & $1,03 \%$ \\
\hline Oost-Nederland & 419.073 & 452.481 & 503.428 & 486.522 & $1,07 \%$ \\
\hline Nederland & 1.296 .902 & 1.379 .454 & 1.545 .816 & 1.505 .125 & $1,07 \%$ \\
\hline \multicolumn{6}{|c|}{ Aantal melkveebedrijven } \\
\hline Berkelland & 363 & 306 & 291 & 261 & $-2,33 \%$ \\
\hline Achterhoek & 1.625 & 1.435 & 1.385 & 1.241 & $-1,91 \%$ \\
\hline Oost-Nederland & 7.052 & 6.214 & 5.914 & 5.305 & $-2,01 \%$ \\
\hline Nederland & 19.713 & 17.519 & 16.699 & 14.923 & $-1,97 \%$ \\
\hline \multicolumn{6}{|c|}{ Aantal melkkoeien per gespecialiseerd melkveebedrijf } \\
\hline Berkelland & 58 & 70 & 80 & 88 & $2,99 \%$ \\
\hline Achterhoek & 61 & 74 & 86 & 93 & $2,99 \%$ \\
\hline Oost-Nederland & 59 & 73 & 85 & 92 & $3,15 \%$ \\
\hline Nederland & 66 & 79 & 93 & 101 & $3,10 \%$ \\
\hline
\end{tabular}

Bron: CBS Landbouwtelling, bewerking Wageningen Economic Research.

Tabel B2.2 Aantal melkkoeien, aantal melkveebedrijven en aantal melkkoeien per gespecialiseerd melkveebedrijf, 2010-2019

\begin{tabular}{|c|c|c|c|c|}
\hline & 2010 & 2015 & 2019 & $\begin{array}{r}\text { mutatie per jaar } \\
(\%)\end{array}$ \\
\hline \multicolumn{5}{|c|}{ Totaal aantal melkkoeien } \\
\hline Berkelland & 21.417 & 23.342 & 22.920 & $0,76 \%$ \\
\hline Achterhoek & 106.323 & 119.250 & 114.867 & $0,86 \%$ \\
\hline Oost-Nederland & 452.481 & 503.428 & 486.522 & $0,81 \%$ \\
\hline Nederland & 1.379 .454 & 1.545 .816 & 1.505 .125 & $0,97 \%$ \\
\hline \multicolumn{5}{|c|}{ Aantal melkveebedrijven } \\
\hline Berkelland & 306 & 291 & 261 & $-1,75 \%$ \\
\hline Achterhoek & 1.435 & 1.385 & 1.241 & $-1,60 \%$ \\
\hline Oost-Nederland & 6.214 & 5.914 & 5.305 & $-1,74 \%$ \\
\hline Nederland & 17.519 & 16.699 & 14.923 & $-1,77 \%$ \\
\hline \multicolumn{5}{|c|}{ Aantal melkkoeien per gespecialiseerd melkveebedrijf } \\
\hline Berkelland & 70 & 80 & 88 & $2,55 \%$ \\
\hline Achterhoek & 74 & 86 & 93 & $2,50 \%$ \\
\hline Oost-Nederland & 73 & 85 & 92 & $2,60 \%$ \\
\hline Nederland & 79 & 93 & 101 & $2,79 \%$ \\
\hline
\end{tabular}

Bron: CBS Landbouwtelling, bewerking Wageningen Economic Research. 
Tabel B2.3 Aantal varkens, aantal varkensbedrijven, aantal varkens per gespecialiseerd varkensbedrijf, 2005-2019

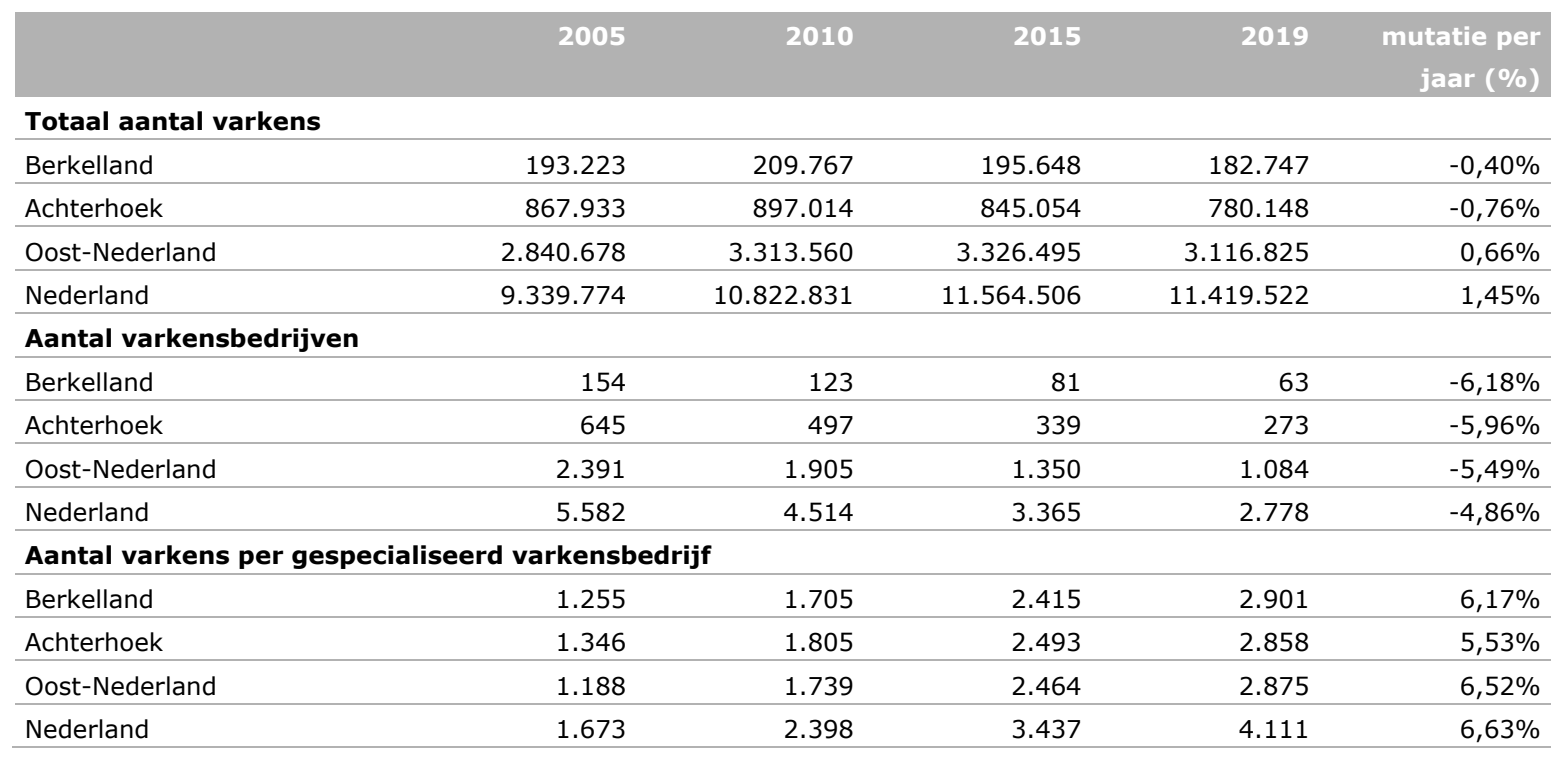

Bron: CBS Landbouwtelling, bewerking Wageningen Economic Research.

Tabel B2.4 Aantal varkens, aantal varkensbedrijven, aantal varkens per gespecialiseerd varkensbedrijf, 2010-2019

\begin{tabular}{|c|c|c|c|c|}
\hline & 2010 & 2015 & 2019 & mutatie per jaar \\
\hline \multicolumn{5}{|c|}{ Totaal aantal varkens } \\
\hline Achterhoek & 897.014 & 845.054 & 780.148 & $-1,54 \%$ \\
\hline Oost-Nederland & 3.313 .560 & 3.326 .495 & 3.116 .825 & $-0,68 \%$ \\
\hline \multicolumn{5}{|c|}{ Aantal varkensbedrijven } \\
\hline Berkelland & 123 & 81 & 63 & $-7,16 \%$ \\
\hline Achterhoek & 497 & 339 & 273 & $-6,44 \%$ \\
\hline Oost-Nederland & 1.905 & 1.350 & 1.084 & $-6,07 \%$ \\
\hline Achterhoek & 1.805 & 2.493 & 2.858 & $5,24 \%$ \\
\hline Oost-Nederland & 1.739 & 2.464 & 2.875 & $5,74 \%$ \\
\hline Nederland & 2.398 & 3.437 & 4.111 & $6,17 \%$ \\
\hline
\end{tabular}

Bron: CBS Landbouwtelling, bewerking Wageningen Economic Research. 
Wageningen Economic Research Postbus 29703

2502 LS Den Haag

T 0703358330

Ecommunications.ssg@wur.nl

www.wur.nl/economic-research

Wageningen Economic Research RAPPORT

2020-075
De missie van Wageningen University \& Research is 'To explore the potential of nature to improve the quality of life'. Binnen Wageningen University \& Research bundelen Wageningen University en gespecialiseerde onderzoeksinstituten van Stichting Wageningen Research hun krachten om bij te dragen aan de oplossing van belangrijke vragen in het domein van gezonde voeding en leefomgeving. Met ongeveer 30 vestigingen, 6.500 medewerkers ( $5.500 \mathrm{fte})$ en 12.500 studenten behoort Wageningen University \& Research wereldwijd tot de aansprekende kennisinstellingen binnen haar domein. De integrale benadering van de vraagstukken en de samenwerking tussen verschillende disciplines vormen het hart van de unieke Wageningen aanpak. 



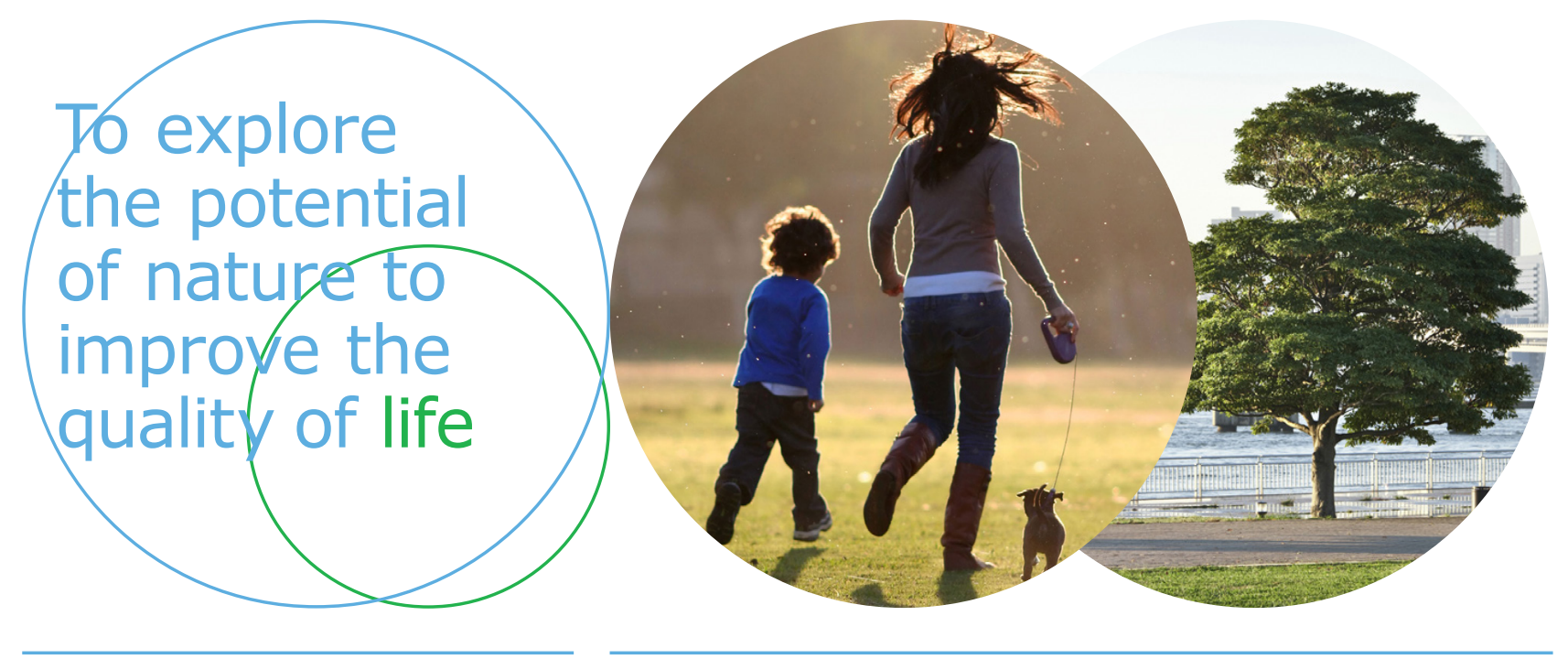

Wageningen Economic Research Postbus 29703

2502 LS Den Haag

T 0703358330

E communications.ssg@wur.nl www.wur.nl/economic-research

Rapport 2020-075

ISBN 978-94-6395-520-1
De missie van Wageningen University \& Research is 'To explore the potential of nature to improve the quality of life'. Binnen Wageningen University \& Research bundelen Wageningen University en gespecialiseerde onderzoeksinstituten van Stichting Wageningen Research hun krachten om bij te dragen aan de oplossing van belangrijke vragen in het domein van gezonde voeding en leefomgeving. Met ongeveer 30 vestigingen, 6.500 medewerkers ( $5.500 \mathrm{fte}$ ) en 12.500 studenten behoort Wageningen University \& Research wereldwijd tot de aansprekende kennisinstellingen binnen haar domein. De integrale benadering van de vraagstukken en de samenwerking tussen verschillende disciplines vormen het hart van de unieke Wageningen aanpak. 